Prepared in cooperation with the Kitsap Public Utility District

\title{
Hydrogeologic Framework, Groundwater Movement, and Water Budget of the Kitsap Peninsula, West-Central Washington
}

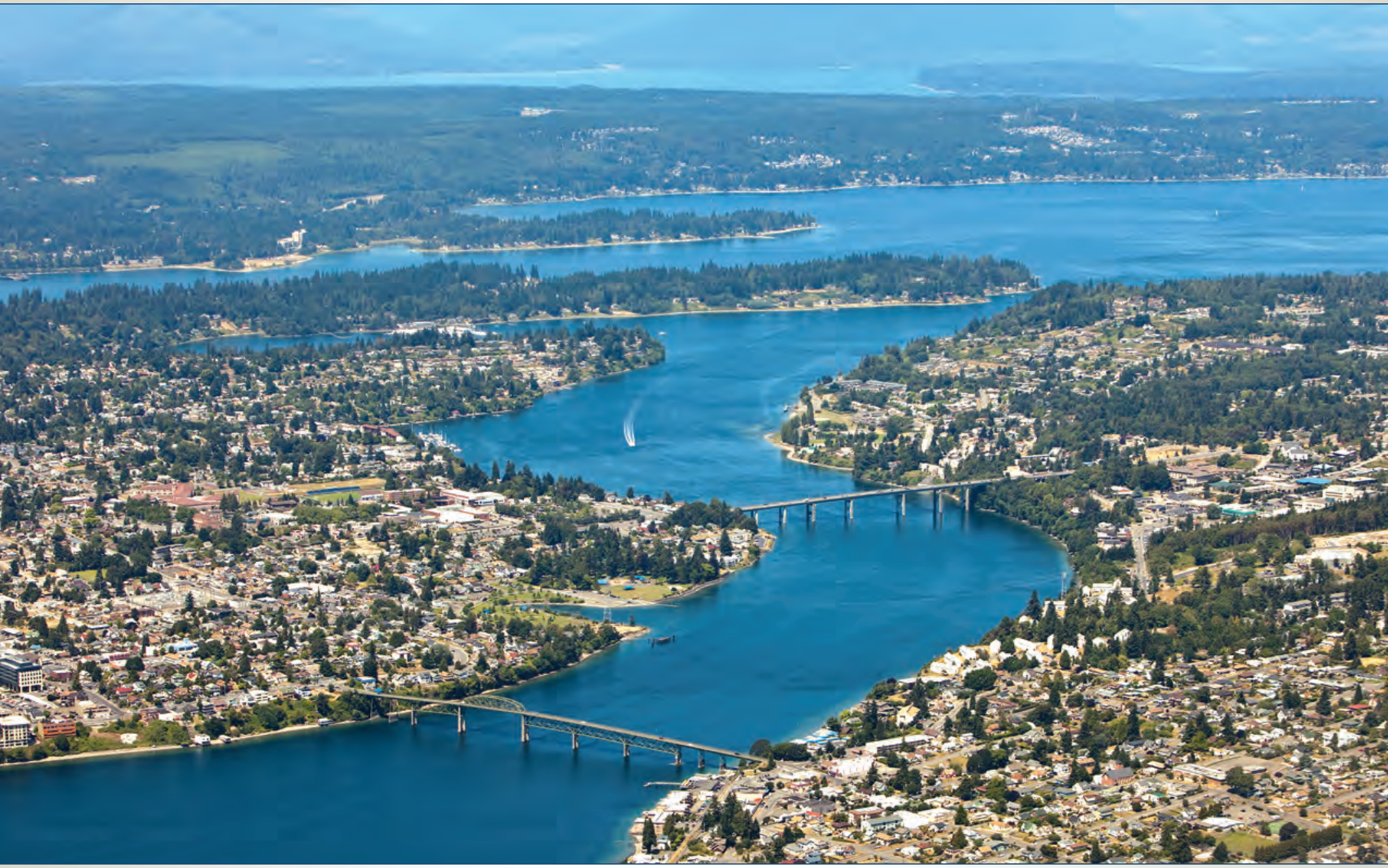

Scientific Investigations Report 2014-5106

U.S. Department of the Interior

U.S. Geological Survey 
Cover: The bridges of Bremerton, connecting East and West Bremerton: Manette Bridge (lower) and Warren Avenue Bridge (upper), July 2009. Dyes Inlet is in the background and Hood Canal farther back. Photograph taken by Jean Boyle, Kitsap Tours, used with permission. 


\section{Hydrogeologic Framework, Groundwater Movement, and Water Budget of the Kitsap Peninsula, West-Central Washington}

By Wendy B. Welch, Lonna M. Frans, and Theresa D. Olsen

Prepared in cooperation with the Kitsap Public Utility District

Scientific Investigations Report 2014-5106 


\title{
U.S. Department of the Interior SALLY JEWELL, Secretary
}

\section{U.S. Geological Survey Suzette M. Kimball, Acting Director}

\author{
U.S. Geological Survey, Reston, Virginia: 2014
}

For more information on the USGS - the Federal source for science about the Earth, its natural and living resources, natural hazards, and the environment, visit http://www.usgs.gov or call 1-888-ASK-USGS

For an overview of USGS information products, including maps, imagery, and publications, visit http://www.usgs.gov/pubprod

To order this and other USGS information products, visit http://store.usgs.gov

Any use of trade, firm, or product names is for descriptive purposes only and does not imply endorsement by the U.S. Government.

Although this information product, for the most part, is in the public domain, it also may contain copyrighted materials as noted in the text. Permission to reproduce copyrighted items must be secured from the copyright owner.

Suggested citation:

Welch, W.B., Frans, L.M., and Olsen, T.D., 2014, Hydrogeologic framework, groundwater movement, and water budget of the Kitsap Peninsula, west-central Washington: U.S. Geological Survey Scientific Investigations Report 2014-5106, 44 p., http://dx.doi.org/10.3133/sir20145106.

ISSN 2328-0328 (online) 


\section{Contents}

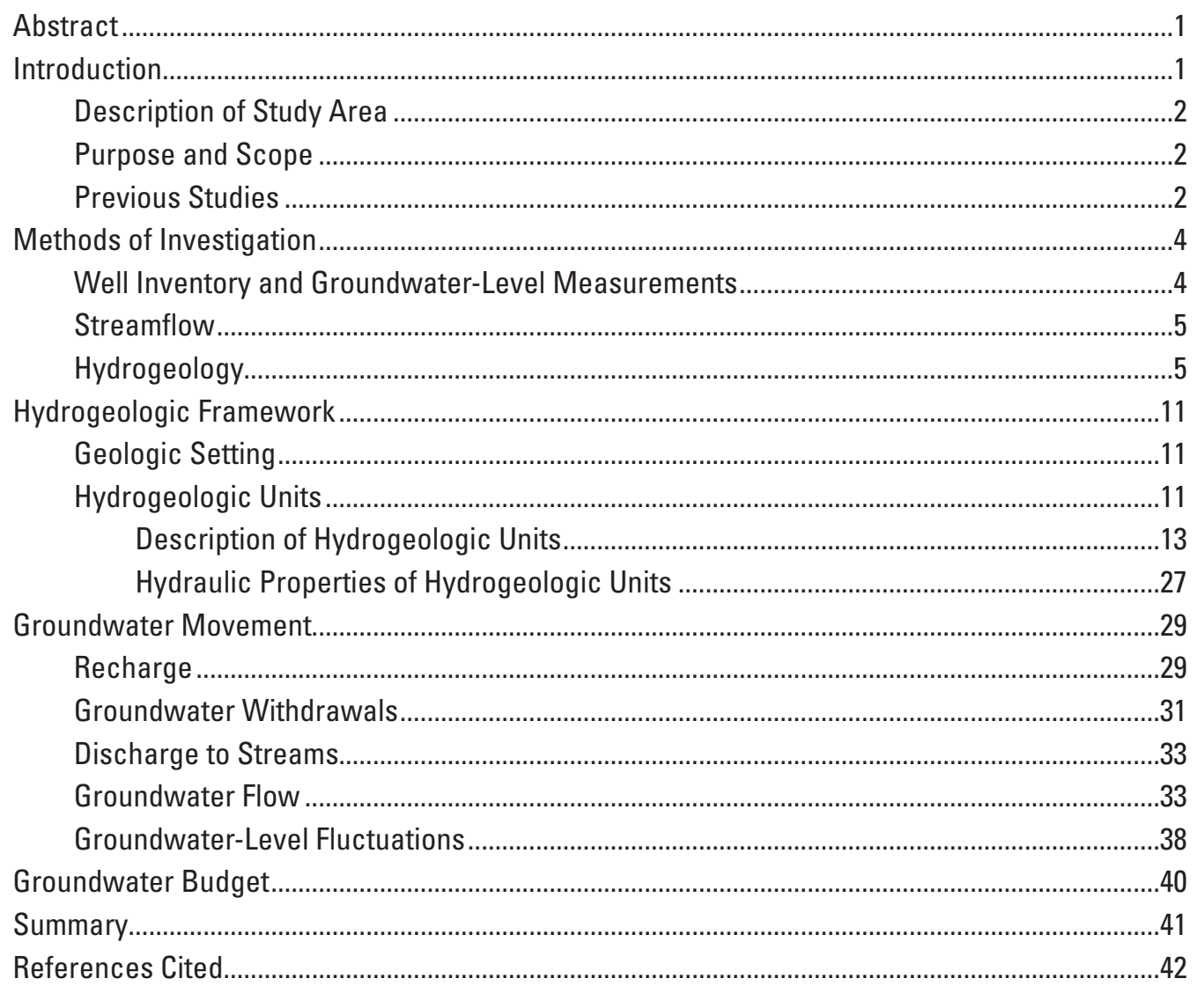




\section{Plates}

[Available for download as a PDF at http://pubs.usgs.gov/sir/2014/5106]

1. Map showing the surficial hydrogeology, cross section traces, and well locations, Kitsap Peninsula, west-central Washington

2. Hydrogeologic sections, Kitsap Peninsula, west-central Washington

\section{Figures}

1. Map showing location of the Kitsap Peninsula study area, west-central Washington.

2. Graphs showing average monthly precipitation and air temperature for Bremerton, Washington, 1981-2010

3. Map showing locations of wells used during the assessment of monthly water levels, Kitsap Peninsula, west-central Washington...

4. Map showing locations of sites where streamflow data were collected, Kitsap Peninsula, west-central Washington, 2011-12

5. Map showing extent and thickness of Vashon recessional aquifer (Qvr), Kitsap Peninsula, west-central Washington.

6. Map showing extent and thickness of Vashon till confining unit (Ovt),

Kitsap Peninsula, west-central Washington.

7. Map showing extent and thickness of Vashon advance aquifer (Qva),

Kitsap Peninsula, west-central Washington.

8. Map showing extent and thickness of the upper confining unit (OC1), Kitsap Peninsula, west-central Washington.

9. Map showing extent and thickness of the permeable interbeds (OC1pi), Kitsap Peninsula, west-central Washington.

10. Map showing extent and thickness of the sea-level aquifer (OA1), Kitsap Peninsula, west-central Washington.

11. Map showing extent and thickness of the middle confining unit (OC2), Kitsap Peninsula, west-central Washington.

12. Map showing extent and thickness of the glaciomarine aquifer (QA2), Kitsap Peninsula, west-central Washington.

13. Map showing extent and thickness of the lower confining unit (OC3), Kitsap Peninsula, west-central Washington.

14. Map showing extent and thickness of the deep aquifer (QA3), Kitsap Peninsula, west-central Washington.

15. Map showing extent and thickness of the basal confining unit (OC4), Kitsap Peninsula, west-central Washington.

16. Map showing extent and depth to the top of the bedrock unit (BR), Kitsap Peninsula, west-central Washington.

17. Graph showing precipitation-groundwater recharge relations and effects of land cover, Kitsap Peninsula, west-central Washington

18. Map showing distribution of average annual recharge from precipitation, Kitsap Peninsula, west-central Washington, 1980-2010 


\section{Figures-Continued}

19. Map showing locations of public-supply wells and pumping rates, Kitsap Peninsula, west-central Washington, 2012.

20. Map showing water-level altitudes and generalized direction of groundwater flow in the Vashon advance aquifer (Ova), Kitsap Peninsula, west-central Washington, autumn 2010 .

21. Map showing water-level altitudes and generalized direction of groundwater flow in the sea level aquifer (OA1), Kitsap Peninsula, west-central Washington, autumn 2010 .

22. Map showing water-level altitudes and generalized direction of flow in the glaciomarine aquifer (QA2), Kitsap Peninsula, west-central Washington, autumn 2010

23. Map showing water-level altitudes and generalized direction of flow in the deep aquifer (QA3), Kitsap Peninsula, west-central Washington, autumn 2010

24. Graph showing water levels in well $22 \mathrm{~N} / 01 \mathrm{E}-29 \mathrm{H} 04$ and discharge at the Huge Creek streamgaging station (12073500), Kitsap Peninsula, west-central

Washington, October 2011-January 2013

25. Graph showing water levels in well 26N/01E-02K02 and discharge at the Dogfish Creek streamgaging station (12070000), Kitsap Peninsula, west-central Washington, October 2011-January 2013

\section{Tables}

1. Description of surface-water sites where streamflow data were collected, Kitsap Peninsula, west-central Washington, 2011-12 ..

2. Base flow discharge data collected by U.S. Geological Survey, Kitsap Peninsula, west-central Washington, 2011-12...

3. Base flow discharge measured by Kitsap Public Utility District, Kitsap Peninsula, west-central Washington, 2011-12.

4. Hydrogeologic unit labels and terminology used in groundwater studies of the Kitsap Peninsula, west-central Washington..

5. Summary of horizontal hydraulic conductivities estimated from specific-capacity data and aquifer tests, by hydrogeologic unit, Kitsap Peninsula, west-central Washington.

6. Monthly mean indoor and outdoor water-use rates for public-supply and self-supplied domestic water use, Kitsap Peninsula, west-central Washington, 1985-2012.

7. Base flow discharge measured at streamgages used to determine groundwater discharge in the Kitsap Peninsula, west-central Washington, 2012.

8. Statistical summary of water-level fluctuations and well depth by hydrogeologic unit, Kitsap Peninsula, west-central Washington, 2011-12..

9. Estimated annual water budget for the groundwater system of the Kitsap

Peninsula, west-central Washington, 2012 


\section{Conversion Factors, Datums, Abbreviations and Acronyms, and Well-Numbering System}

\section{Conversion Factors}

Inch/Pound to SI

\begin{tabular}{|c|c|c|}
\hline Multiply & By & To obtain \\
\hline \multicolumn{3}{|c|}{ Length } \\
\hline inch (in.) & 2.54 & centimeter (cm) \\
\hline foot $(\mathrm{ft})$ & 0.3048 & meter (m) \\
\hline mile (mi) & 1.609 & kilometer (km) \\
\hline \multicolumn{3}{|c|}{ Area } \\
\hline acre & 4,047 & square meter $\left(\mathrm{m}^{2}\right)$ \\
\hline square mile $\left(\mathrm{mi}^{2}\right)$ & 259.0 & hectare (ha) \\
\hline \multicolumn{3}{|c|}{ Volume } \\
\hline acre-foot (acre-ft) & 1,233 & cubic meter $\left(\mathrm{m}^{3}\right)$ \\
\hline \multicolumn{3}{|c|}{ Flow rate } \\
\hline acre-foot per year (acre-ft/yr) & 1,233 & cubic meter per year (m³/yr) \\
\hline foot per day (ft/d) & 0.3048 & meter per day $(\mathrm{m} / \mathrm{d})$ \\
\hline cubic foot per day $\left(\mathrm{ft}^{3} / \mathrm{d}\right)$ & 0.02832 & cubic meter per day (m³/d) \\
\hline cubic foot per second $\left(\mathrm{ft}^{3} / \mathrm{s}\right)$ & 0.02832 & cubic meter per second $\left(\mathrm{m}^{3} / \mathrm{s}\right)$ \\
\hline inch per year (in/yr) & 25.4 & millimeter per year (mm/yr) \\
\hline \multicolumn{3}{|c|}{ Water use rate } \\
\hline gallon per person per day (gal/d) & 0.003785 & $\begin{array}{l}\text { cubic meter per person per day } \\
\qquad\left(\mathrm{m}^{3} / \mathrm{d}\right)\end{array}$ \\
\hline \multicolumn{3}{|c|}{ Hydraulic conductivity } \\
\hline foot per day (ft/d) & 0.3048 & meter per day (m/d) \\
\hline \multicolumn{3}{|c|}{ Transmissivity* } \\
\hline foot squared per day (ft²/d) & 0.09290 & meter squared per day (m²/d) \\
\hline
\end{tabular}

Temperature in degrees Fahrenheit $\left({ }^{\circ} \mathrm{F}\right)$ may be converted to degrees Celsius $\left({ }^{\circ} \mathrm{C}\right)$ as follows:

$$
{ }^{\circ} \mathrm{C}=\left({ }^{\circ} \mathrm{F}-32\right) / 1.8 \text {. }
$$

*Transmissivity: The standard unit for transmissivity is cubic foot per day per square foot times foot of aquifer thickness [(ft $\left.\left.\mathrm{ft}^{3} / \mathrm{d}\right) / \mathrm{ft}^{2}\right] \mathrm{ft}$. In this report, the mathematically reduced form, foot squared per day $\left(\mathrm{ft}^{2} / \mathrm{d}\right)$, is used for convenience.

\section{Datums}

Vertical coordinate information is referenced to the North American Vertical Datum of 1988 (NAVD 88).

Horizontal coordinate information is referenced to the North American Datum of 1983 (NAD 83). Altitude, as used in this report, refers to distance above the vertical datum. 


\section{Conversion Factors, Datums, Abbreviations and Acronyms, and Well-Numbering System-Continued}

\section{Abbreviations and Acronyms}

$\begin{array}{ll}\text { ANUDEM } & \text { Australian National University Digital Elevation Model } \\ \text { DEM } & \text { digital elevation model } \\ \text { GIS } & \text { geographic information system } \\ \text { KPUD } & \text { Kitsap Public Utility District } \\ \text { lidar } & \text { Light Detection and Ranging } \\ \text { PRISM } & \text { Parameter-elevation Regressions on Independent Slopes model } \\ \text { USGS } & \text { U.S. Geological Survey }\end{array}$

\section{Well-Numbering System}

In the State of Washington, wells and springs are assigned numbers that identify their location within a township, range, section, and 40-acre tract. For example, local well number $25 \mathrm{~N} / 02 \mathrm{E}-15001$ indicates that the well is in township 25 north and range 2 east, north and east of the Willamette Base Line and Meridian, respectively. The numbers immediately following the hyphen indicate the section (15) within the township; the letter (0) following the section gives the 40 -acre tract of the section. The two-digit sequence number (01) following the letter indicates that the well was the first one inventoried by U.S. Geological Survey personnel in that 40 -acre tract. An "S," “D," or " $P$ " following the sequence number indicates that the site is a spring, deepened well, or piezometer in a well, respectively. In the figures of this report, wells and springs are identified individually by only the section and 40 -acre tract, such as 15001; township and range are shown on the map borders.

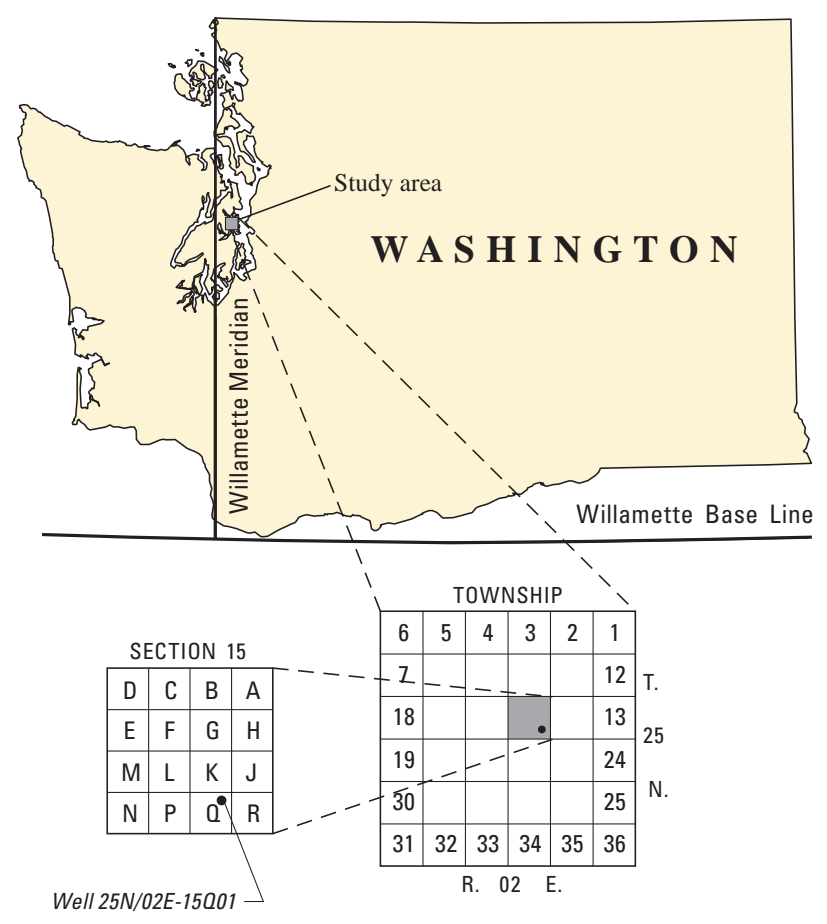





\title{
Hydrogeologic Framework, Groundwater Movement, and Water Budget of the Kitsap Peninsula, West-Central Washington
}

\author{
By Wendy B. Welch, Lonna M. Frans, and Theresa D. Olsen
}

\section{Abstract}

This report presents information used to characterize the groundwater-flow system on the Kitsap Peninsula, and includes descriptions of the geology and hydrogeologic framework, groundwater recharge and discharge, groundwater levels and flow directions, seasonal groundwater-level fluctuations, interactions between aquifers and the surface-water system, and a water budget. The Kitsap Peninsula is in the Puget Sound lowland of west-central Washington, is bounded by Puget Sound on the east and by Hood Canal on the west, and covers an area of about 575 square miles. The peninsula encompasses all of Kitsap County, the part of Mason County north of Hood Canal, and part of Pierce County west of Puget Sound. The peninsula is surrounded by saltwater and the hydrologic setting is similar to that of an island. The study area is underlain by a thick sequence of unconsolidated glacial and interglacial deposits that overlie sedimentary and volcanic bedrock units that crop out in the central part of the study area. Geologic units were grouped into 12 hydrogeologic units consisting of aquifers, confining units, and an underlying bedrock unit. A surficial hydrogeologic unit map was developed and used with well information from 2,116 drillers' logs to construct 6 hydrogeologic sections and unit extent and thickness maps.

Unconsolidated aquifers typically consist of moderately to well-sorted alluvial and glacial outwash deposits of sand, gravel, and cobbles, with minor lenses of silt and clay. These units often are discontinuous or isolated bodies and are of highly variable thickness. Unconfined conditions occur in areas where aquifer units are at land surface; however, much of the study area is mantled by glacial till, and confined aquifer conditions are common. Groundwater in the unconsolidated aquifers generally flows radially off the peninsula in the direction of Puget Sound and Hood Canal. These generalized flow patterns likely are complicated by the presence of low-permeability confining units that separate discontinuous bodies of aquifer material and act as local groundwater-flow barriers.
Groundwater-level fluctuations observed during the monitoring period (2011-12) in wells completed in unconsolidated hydrogeologic units indicated seasonal variations ranging from 1 to about 20 feet. The largest fluctuation of 33 feet occurred in a well that was completed in the bedrock unit. Streamgage discharge measurements made during 2012 indicate that groundwater discharge to creeks in the area ranged from about 0.41 to 33.3 cubic feet per second.

During 2012, which was an above-average year of precipitation, the groundwater system received an average of about 664,610 acre-feet of recharge from precipitation and 22,122 acre-feet of recharge from return flows. Most of this annual recharge (66 percent) discharged to streams, and only about 4 percent was withdrawn from wells. The remaining groundwater recharge (30 percent) left the groundwater system as discharge to Hood Canal and Puget Sound.

\section{Introduction}

Groundwater is the primary source of drinking water for most of the population of the Kitsap Peninsula (Lane, 2009). Consequently, as the population grows, so does the demand for groundwater. The quantity of usable groundwater likely is limited, however, mostly because of the peninsula geography and the potential for declines in water levels, decreases in the groundwater discharge to streams, and seawater intrusion as groundwater usage increases.

At a series of public meetings in 2009 to discuss the U.S. Geological Survey (USGS) Bainbridge Island groundwater study (Frans and others, 2011), water managers from the Kitsap Public Utility District (KPUD), and several water purveyors on the Kitsap Peninsula expressed a desire for an integrated peninsula groundwater model for managing their water resources. The Kitsap Peninsula shares several characteristics with Bainbridge Island, and the two areas face similar issues of limited groundwater recharge because of overlying low-permeability glacial tills, increasing demands for groundwater supplies, and potential saltwater intrusion 
near coastal wells. The geographic proximity of the two areas to each other also raises questions about potential connectivity between aquifers on the peninsula and the island, with groundwater pumping practices in one area potentially affecting groundwater storage in the other. Although the Bainbridge Island study was confined to the island and nearby parts of the peninsula, a larger model of the Kitsap Peninsula, extended to natural hydrologic barriers, would provide a more complete picture of regional groundwater supplies, and would become a valuable tool for water managers coordinating regional water-management plans. As a result of these discussions, the USGS and KPUD, with interlocal agreements between numerous other water purveyors, entered into a joint agreement to fund the development of a hydrogeologic framework and numerical model of the Kitsap Peninsula.

\section{Description of Study Area}

The Kitsap Peninsula is in the Puget Sound lowland of west-central Washington (fig. 1), is bounded by Puget Sound on the east and Hood Canal on the west, and covers an area of about $575 \mathrm{mi}^{2}$. The peninsula encompasses all of Kitsap County, the part of Mason County that is north of Hood Canal and a part of Pierce County that is west of Puget Sound. The study area was selected to include hydrologic boundaries that could be used as model boundaries in numerical simulations of the groundwater flow system to be described in a subsequent report. The peninsula is surrounded by saltwater and has a hydrologic setting similar to that of an island. Many coastal areas are steep, with altitudes ranging from 0 to $500 \mathrm{ft}$ or more. Inland, slopes generally are moderate, and many areas are nearly flat with the exception of Green and Gold Mountains, which are in the central part of the peninsula with altitudes of more than $1,700 \mathrm{ft}$. Glacial and interglacial deposits that constitute much of the subsurface of the study area are exposed in cliffs along many shorelines. The deposits consist primarily of alternating layers of glacial till, sand and gravel, and silt and clay. Bedrock, which underlies the glacial and interglacial deposits, ranges in depth from exposure at the land surface to an estimated 2,000 ft below land surface (Jones, 1996).

The study area is incised by rivers and streams that flow from the interior of the Kitsap Peninsula to Puget Sound and Hood Canal. Many rivers and streams flow year-round and are fed by springs and surface runoff after storms. Where cliffs are present along the coastline, springs and seeps discharge water directly onto the beach and into Puget Sound.

The study area has a temperate marine climate that is typical of the Puget Sound lowland, with warm, dry summers and cool, wet winters. Precipitation amounts are controlled largely by the Olympic Mountains to the west and the Cascade Range to the east, which impede the flow of humid air masses that are generated over the Pacific Ocean. The long-term average annual precipitation at Bremerton, Washington (fig. 1), in the central part of the study area, is 56.37 in/yr for 1981-2010 (Western Region Climate Center, 2013); November and December are the wettest months and July and August are the driest months (fig. 2A). Precipitation at Bremerton during the 2 years of data collection for this study was 52.84 in. during 2011 and 69.66 in. during 2012. These amounts are 93.7 percent and 123 percent of the long term average, respectively. Temperatures are mild throughout the year. The average monthly maximum temperature is $76.6^{\circ} \mathrm{F}$ in August and the average monthly minimum is $34.5^{\circ} \mathrm{F}$ in December (fig. 2B). At times, winter temperatures are sufficiently low for a few inches of snow to accumulate; however, snow accumulation typically is not significant or long lasting.

\section{Purpose and Scope}

This report describes the hydrogeologic framework and groundwater flow in the Kitsap Peninsula study area. The topics covered in this report describe the geologic history of the study area, the surficial geology of the Kitsap Peninsula, the physical characteristics of individual hydrogeologic units, groundwater levels and flow directions, seasonal groundwaterlevel fluctuations, and a simplified groundwater budget.

\section{Previous Studies}

The geology and groundwater resources of the Kitsap Peninsula have been described in previous reports. The first of these reports (Sceva, 1957) described the groundwater resources of Kitsap County, and a subsequent report by Garling and others (1965) described the groundwater and surface-water resources of the Kitsap Peninsula. Deeter (1979) described the geology and stratigraphy of Kitsap County, and Hansen and Bolke (1980) described groundwater availability on the Kitsap Peninsula. A comprehensive update of the water resources of Kitsap County was prepared by the Kitsap County Ground Water Advisory Committee and others (1989) as part of the Kitsap County groundwater-management plan, and included hydrogeologic cross sections and determination of principal aquifers. Many other published studies have covered small parts of the Kitsap Peninsula, such as Lum (1979) in the Port Madison Indian Reservation area, Drost (1982) for the Gig Harbor Peninsula, Dion and others (1988) for Bainbridge Island, and Kahle (1998) in the Naval Base Kitsap-Bangor area. Most recently, a hydrogeologic framework and numerical model was constructed for Bainbridge Island and surrounding areas (Frans and others, 2011). 


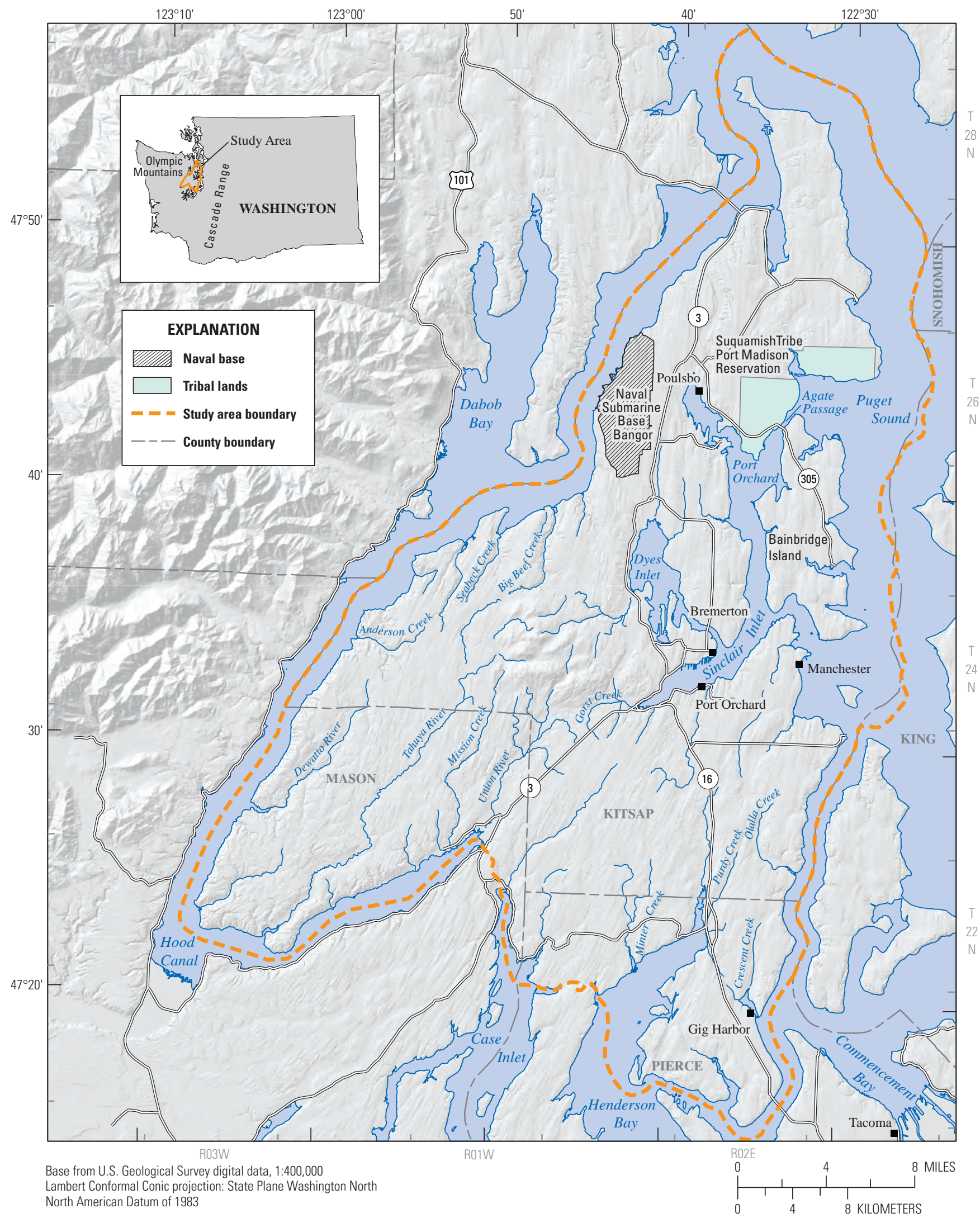

Figure 1. Location of the Kitsap Peninsula study area, west-central Washington. 

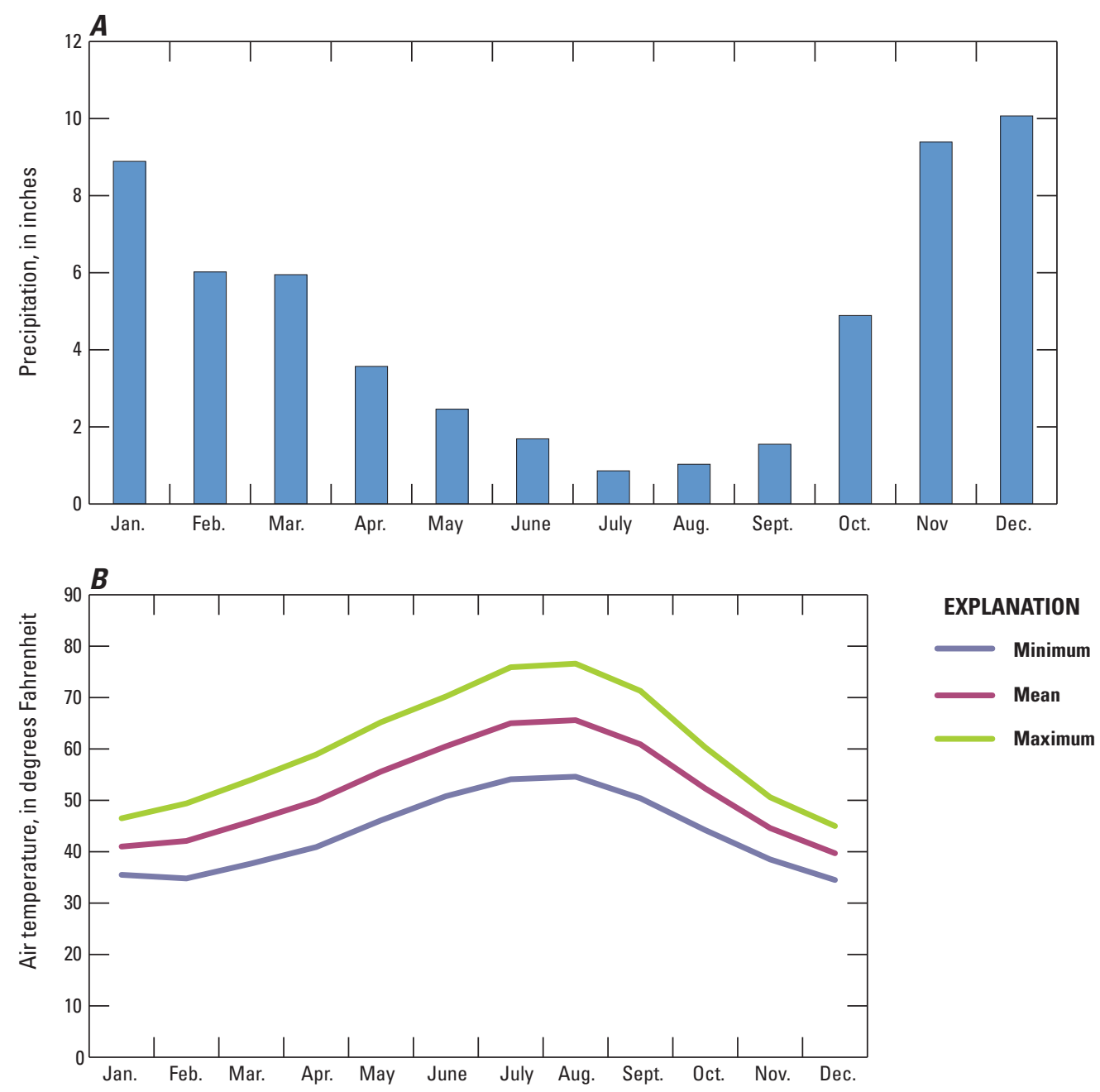

Figure 2. (A) Average monthly precipitation and $(B)$ air temperature for Bremerton, Washington, 1981-2010.

\section{Methods of Investigation}

Lithologic logs, groundwater-level measurements in wells, streamflow measurements, and precipitation and other meteorological data were the primary sources of information used to define the current hydrogeologic framework and groundwater and surface-water systems. The hydrogeologic framework was constructed by correlating the lithology between individual wells described in drillers' well logs. Groundwater flow and hydraulic properties of the aquifers were estimated by measuring water levels and using well-pumpage data, respectively. Groundwater recharge was estimated using the regression method of Bidlake and Payne (2001), which uses precipitation, land-cover, and soils data.

\section{Well Inventory and Groundwater-Level Measurements}

The groundwater-flow system was characterized based on the analysis of spatially distributed information about groundwater levels, and the physical and hydraulic properties of the geologic units documented during well construction. Spatial information was obtained through the measurement of water levels in wells, and the compilation and analysis of hydrogeologic descriptions and well tests from well drillers' logs. Well records that document the drilling (drillers' log description of borehole lithology), construction, and hydraulic testing of wells were compiled from USGS and Washington State Department of Ecology databases to identify candidate wells for this study. 
Candidate wells were selected for field inventory based on the location and depth of the well, and the availability of a complete well record with drillers' log. Well records with insufficient well location and construction information or incomplete or poorly constrained drillers' logs were not used in this study. The goal of the inventory was to obtain an even distribution of wells throughout the study area and within each aquifer. However, this was not possible for the entire study area because of a lack of wells in less-populated areas.

Data from 2,116 wells were used in this study (pl. 1). During a field inventory in autumn and winter 2010, permission was obtained from selected well owners and synoptic water-level measurements were made, where possible, in more than 190 wells. Data from an additional 1,910 wells were collected during previous studies of the area. Water levels were measured by the USGS in 66 wells approximately monthly over a 2-year period (ig. 3). Additionally, water levels were measured by water purveyors in the area in many public supply wells.

Latitude and longitude locations were determined for each well during the field inventory using a Global Positioning System receiver with a horizontal accuracy of one-tenth of a second (about $10 \mathrm{ft}$ ). Light detection and ranging (lidar) data were obtained through the Puget Sound LiDAR Consortium (2000), were resampled from 6- to 100-ft resolution, and then were used to determine the altitude of the land surface at each well and to subsequently compute water-level altitudes. Vertical accuracy of the lidar data typically was plus or minus $1 \mathrm{ft}$.

Water levels, reported as depth to water below land surface, were measured using a calibrated electric tape or graduated steel tape, both with a stated accuracy of $0.01 \mathrm{ft}$. All water-level measurements were made in accordance with standard techniques of the USGS (Cunningham and Schalk, 2011). Water-level altitudes were determined by subtracting the measured depth-to-water below land surface from the lidar derived land-surface altitude at the well.

\section{Streamflow}

USGS personnel measured synoptic stream base flow approximately 6 times at 26 sites over the summers of 2011 and 2012 (fig. 4, tables 1 and 2). The KPUD measured stream base flow approximately 6 times at 28 additional sites over the summers of 2011 and 2012 (fig. 4, tables 1 and $\underline{3}$ ). These data were used to quantify the amount of surface water leaving the study area. Streamflow measurements were made by USGS using Price (pygmy or AA) or FlowTracker Handheld ADV ${ }^{\circledR}$ current velocity meters or flumes according to standard techniques of the USGS (Rantz, 1982).

Streamflow measurements were made by KPUD using a Swoffer Model 2100 Current Velocity Meter. Flow in small streams was measured using volumetric techniques.

\section{Hydrogeology}

The hydrogeologic framework describes the boundaries and lithology of the hydrogeologic units (aquifers and confining units) in the study area. This framework is described by a map of the surficial hydrogeologic units and cross sections of the subsurface (pls. 1 and 2), and maps of areal extent and thickness of the hydrogeologic units (igs. 5-16). Drillers' logs of wells containing descriptions of lithology were the primary source of information. Much of the hydrogeologic analysis was done using a geographic information system (GIS) that included spatial databases of locations and lithologic information for more than 2,100 wells, surficial geology from multiple sources and at varying scales, and lidar digital land-surface altitudes.

The surficial hydrogeologic map for the study area (pl. 1; scale 1:80,000) was produced by merging available digital surficial geologic and hydrogeologic maps (Yount and Gower, 1991, scale 1:100,000; Kahle, 1998, scale 1:62,500; Booth and Troost, 2005, scale 1:24,000; Logan and others, 2006, scale 1:24,000; Derkey and others, 2009, scale 1:24,000; Polenz and others, 2009a, scale 1:24,000; Polenz and others, 2009b, scale 1:24,000; Contreras and others, 2010, scale 1:24,000; Contreras and others, 2011, scale 1:24,000; Frans and others, 2011, scale 1:100,000; and Tabor and others, 2011, scale 1:24,000) with scanned and digitized geologic maps by Troost and others (K.G. Troost, D.B. Booth, and R.E. Wells, U.S. Geological Survey, unpub. data, 2014). More than 50 geologic units delineated on these source maps were grouped into 12 hydrogeologic units based on similarities in lithology (grain size and sorting), hydrologic characteristics, and relative stratigraphic position.

The surficial hydrogeologic map and lithologic data from 2,116 drillers' logs were used to construct multiple hydrogeologic cross sections using Aquaveo ${ }^{\mathrm{TM}}$ 's ArcHydro Subsurface Analyst tools for ArcGIS to identify and correlate the hydrogeologic units in the subsurface. Six representative sections, using lithologic information from 274 wells, are shown on plate 2. Hydrogeologic unit assignments were used to delineate the extent of each unit throughout the study area. The altitude of the top surface of a unit was interpolated in a GIS at a 100-ft interpolation grid cell size, using a method based on the Australian National University Digital Elevation Model (ANUDEM) procedure developed by Hutchinson (1989). Hydrogeologic unit top surfaces were constrained to the lidar-derived land surface digital elevation model (DEM) at locations where the units cropped out. If part of the top surface of a unit was interpolated higher than the top of an overlying unit, then minimum thickness values for the overlying unit were used in the calculations to adjust the altitude of the top of the underlying unit where needed. Unit thickness maps were created by using GIS to calculate the difference between the top of a unit and the interpolated top of the underlying unit or units. The altitude of the top of bedrock was calculated in a GIS using contours representing the top of the basement confining unit from Jones (1999), land surface altitudes where bedrock outcrops, and point elevation values from 46 wells that penetrated bedrock in the study area. 


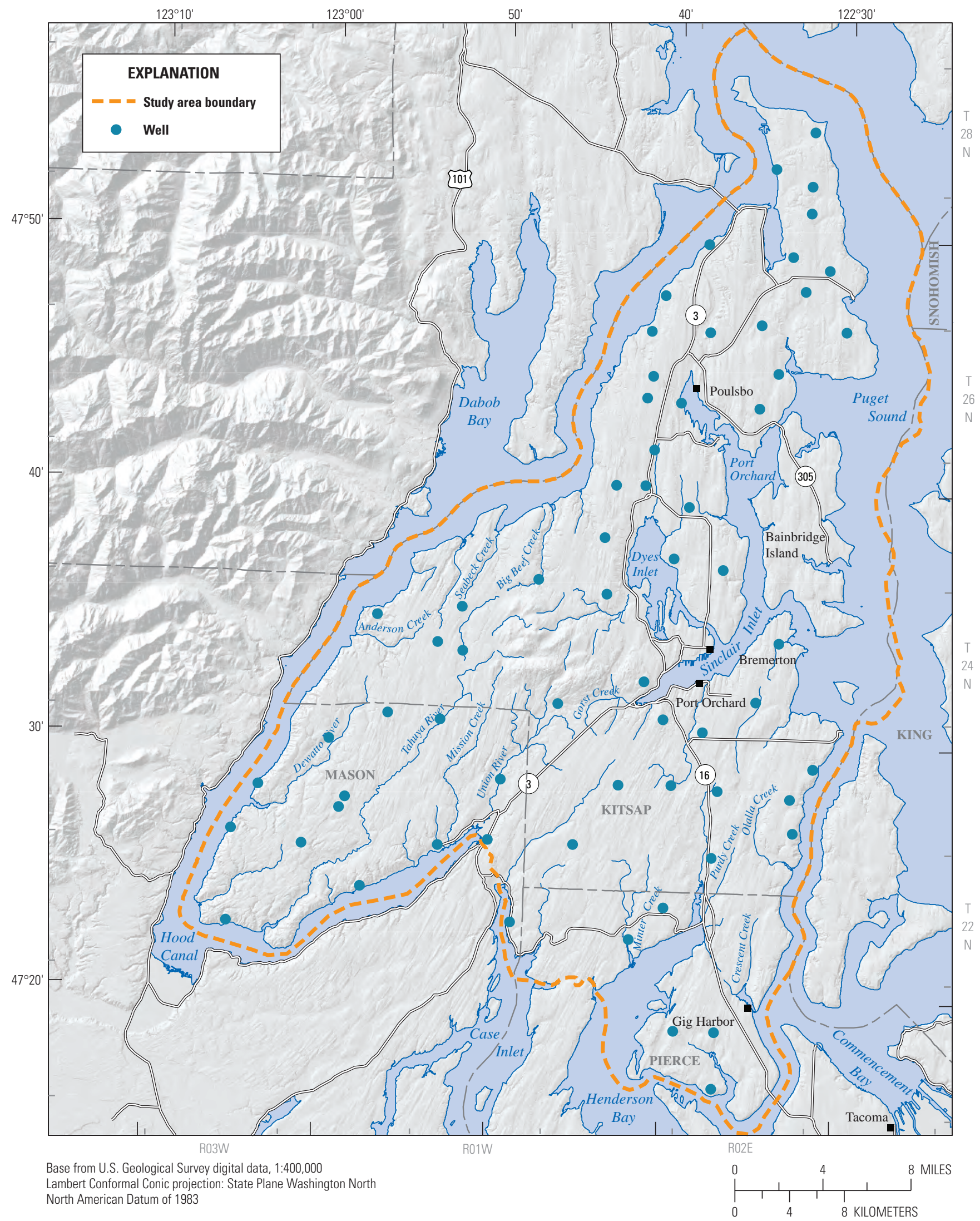

Figure 3. Locations of wells used during the assessment of monthly water levels, Kitsap Peninsula, west-central Washington. 


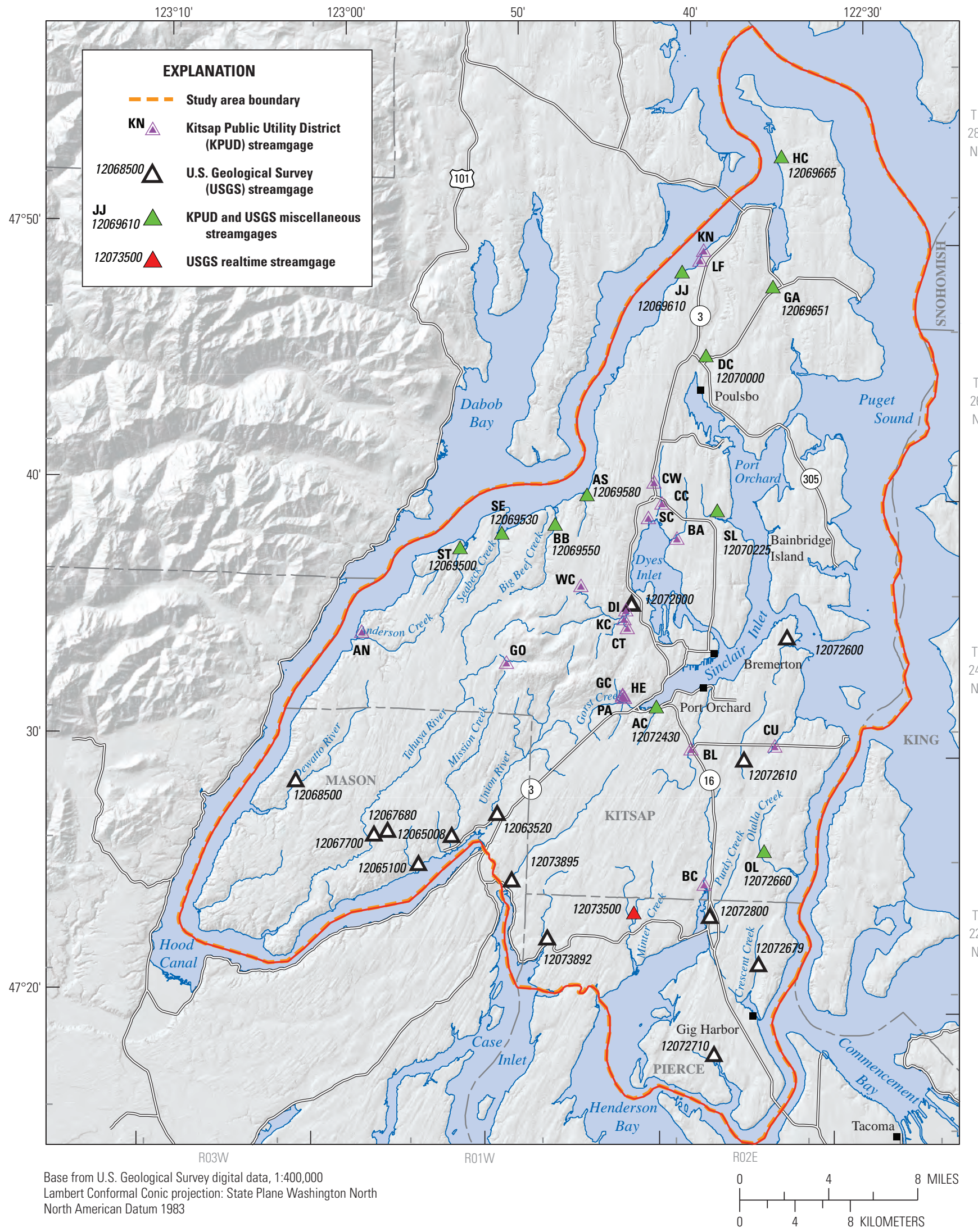

Figure 4. Locations of sites where streamflow data were collected, Kitsap Peninsula, west-central Washington, 2011-12. 
Table 1. Description of surface-water sites where streamflow data were collected, Kitsap Peninsula, west-central Washington, 2011-12.

[Locations of sites are shown in figure 4. -, not measured by that agency]

\begin{tabular}{|c|c|c|c|c|}
\hline $\begin{array}{c}\text { USGS } \\
\text { station } \\
\text { No. }\end{array}$ & $\begin{array}{c}\text { KPUD } \\
\text { identifier }\end{array}$ & Site name & $\begin{array}{l}\text { Decimal } \\
\text { latitude }\end{array}$ & $\begin{array}{c}\text { Decimal } \\
\text { longitude }\end{array}$ \\
\hline 12072430 & $\mathrm{AC}$ & Anderson Creek near Anderson Road near Gorst & 47.524 & -122.683 \\
\hline- & $\mathrm{AN}$ & Anderson Creek - Holly & 47.567 & -122.968 \\
\hline 12069580 & AS & Anderson Creek near Warrenville & 47.660 & -122.755 \\
\hline 12072710 & - & Artondale Creek at Artondale & 47.298 & -122.619 \\
\hline- & BA & Barker Creek & 47.639 & -122.667 \\
\hline 12072600 & - & Beaver Creek near Manchester & 47.571 & -122.560 \\
\hline 12069550 & $\mathrm{BB}$ & Big Beef Creek near Seabeck & 47.641 & -122.785 \\
\hline- & $\mathrm{BC}$ & Burley Creek & 47.414 & -122.631 \\
\hline- & BL & Blackjack Creek & 47.502 & -122.648 \\
\hline 12072000 & - & Chico Creek near Bremerton & 47.590 & -122.710 \\
\hline- & CC & Clear Creek - main stem & 47.661 & -122.682 \\
\hline- & CT & Chico Creek - tributary & 47.580 & -122.716 \\
\hline- & $\mathrm{CU}$ & Curley Creek & 47.505 & -122.567 \\
\hline- & CW & Clear Creek - west tributary & 47.670 & -122.692 \\
\hline 12073895 & - & Coulter Creek near Allyn & 47.408 & -122.817 \\
\hline 12072679 & - & Crescent Creek at Crescent Valley Drive near Gig Harbor & 47.358 & -122.578 \\
\hline 12068500 & - & Dewatto River near Dewatto & 47.469 & -123.027 \\
\hline 12070000 & DC & Dogfish Creek near Poulsbo & 47.753 & -122.645 \\
\hline- & DI & Dickerson Creek & 47.586 & -122.715 \\
\hline 12069651 & GA & Gamble Creek near Port Gamble & 47.799 & -122.582 \\
\hline- & GC & Gorst Creek - main stem & 47.530 & -122.716 \\
\hline- & GO & Gold Creek & 47.555 & -122.827 \\
\hline 12069665 & $\mathrm{HC}$ & Hansville Creek near Port Gamble & 47.884 & -122.577 \\
\hline- & HE & Heins Creek & 47.531 & -122.716 \\
\hline 12073500 & - & Huge Creek near Wauna & 47.389 & -122.699 \\
\hline 12069610 & $\mathrm{JJ}$ & Jumpoff Joe Creek at mouth near Lofall & 47.807 & -122.670 \\
\hline- & $\mathrm{KC}$ & Kitsap Creek & 47.580 & -122.712 \\
\hline- & $\mathrm{KN}$ & Kinman Creek & 47.821 & -122.650 \\
\hline- & $\mathrm{LF}$ & Lofall Creek & 47.815 & -122.653 \\
\hline 12065008 & - & Mission Creek at Mission Creek Road near Belfair & 47.436 & -122.876 \\
\hline 12072660 & $\mathrm{OL}$ & Olalla Creek at Burley Olalla Road, Olalla & 47.431 & -122.576 \\
\hline- & PA & Parish Creek & 47.529 & -122.714 \\
\hline 12072800 & - & Purdy Creek at Purdy & 47.388 & -122.626 \\
\hline 12073892 & - & Rocky Creek near mouth near Allyn & 47.371 & -122.782 \\
\hline 12072610 & - & Salmonberry Creek near mouth near Bethel & 47.491 & -122.598 \\
\hline- & SC & Strawberry Creek & 47.647 & -122.696 \\
\hline 12069530 & $\mathrm{SE}$ & Seabeck Creek near mouth near Seabeck & 47.634 & -122.836 \\
\hline 12070225 & SL & Steel Creek near mouth near Brownsville & 47.652 & -122.630 \\
\hline 12069500 & $\mathrm{ST}$ & Stavis Creek near Seabeck & 47.623 & -122.876 \\
\hline 12065100 & - & Stimson Creek at North Shore Road near Belfair & 47.417 & -122.907 \\
\hline 12067700 & - & Tahuya River below Haven Way near Belfair & 47.436 & -122.951 \\
\hline 12067680 & - & Tahuya River Tributary No. 2 near Belfair-Tahuya Road & 47.438 & -122.938 \\
\hline 12063520 & - & Union River at North Shore Road near Belfair & 47.451 & -122.833 \\
\hline- & WC & Wildcat Creek & 47.601 & -122.759 \\
\hline
\end{tabular}


Table 2. Base flow discharge data collected by U.S. Geological Survey, Kitsap Peninsula, west-central Washington, 2011-12.

[ $\mathrm{ft}^{3} / \mathrm{s}$, cubic foot per second]

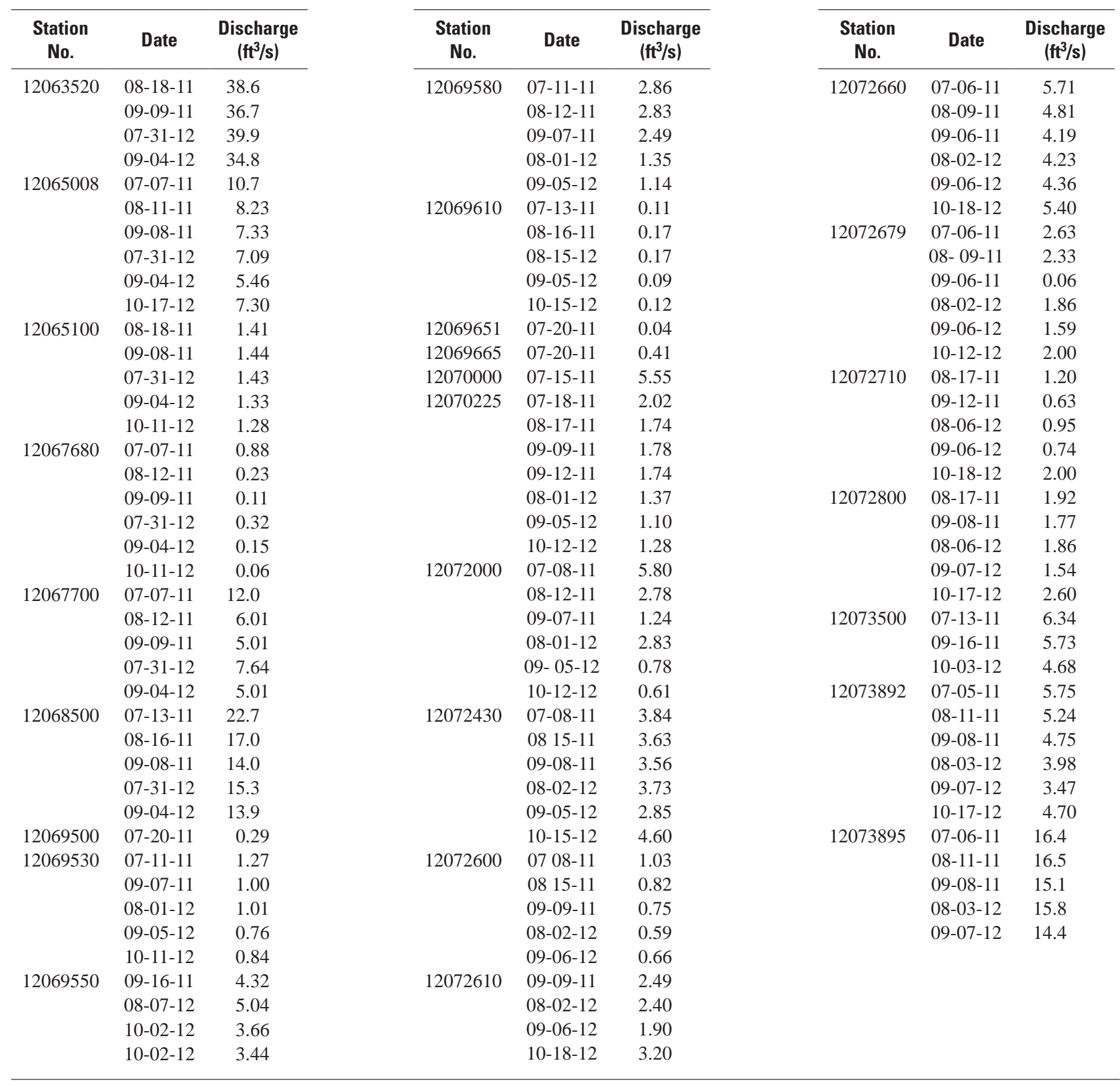


Table 3. Base flow discharge measured by Kitsap Public Utility District, Kitsap Peninsula, west-central Washington, $2011-12$.

[Description of KPUD stream identifier is shown in table $1 . \mathrm{ft}^{3} / \mathrm{s}$, cubic foot per second]

\begin{tabular}{|c|c|c|c|c|c|c|c|c|}
\hline $\begin{array}{c}\text { KPUD } \\
\text { stream } \\
\text { identifier }\end{array}$ & Date & $\begin{array}{c}\text { Discharge } \\
\left(\mathrm{ft}^{3} / \mathrm{s}\right)\end{array}$ & $\begin{array}{c}\text { KPUD } \\
\text { stream } \\
\text { identifier }\end{array}$ & Date & $\begin{array}{c}\text { Discharge } \\
\left(\mathrm{ft}^{3} / \mathrm{s}\right)\end{array}$ & $\begin{array}{c}\text { KPUD } \\
\text { stream } \\
\text { identifier }\end{array}$ & Date & $\begin{array}{c}\text { Discharge } \\
\left(\mathrm{ft}^{3} / \mathrm{s}\right)\end{array}$ \\
\hline \multirow{3}{*}{ AC } & 09-09-11 & 3.29 & & $07-31-12$ & 2.82 & & $08-12-11$ & 1.18 \\
\hline & $10-07-11$ & 3.19 & & 08-13-12 & 2.83 & & 09-07-11 & 0.71 \\
\hline & $07-26-12$ & 3.29 & & 09-13-12 & 2.66 & & $09-27-11$ & 3.10 \\
\hline \multirow[t]{6}{*}{$\mathrm{AN}$} & 07-07-11 & 7.64 & & $08-30-11$ & 4.50 & $\mathrm{KN}$ & $07-29-11$ & 1.21 \\
\hline & 08-11-11 & 6.80 & & $07-26-12$ & 4.67 & & 08-30-11 & 0.91 \\
\hline & 09-15-11 & 6.49 & & 08-13-12 & 4.16 & & $09-30-11$ & 1.17 \\
\hline & $07-30-12$ & 6.70 & & 09-07-12 & 3.72 & & $07-31-12$ & 1.80 \\
\hline & 08-28-12 & 6.05 & DI & $07-07-11$ & 1.09 & & $08-22-12$ & 0.84 \\
\hline & $09-27-12$ & 5.99 & & $08-12-11$ & 0.79 & LF & $07-29-11$ & 0.14 \\
\hline \multirow{2}{*}{ AS } & $08-22-12$ & 2.51 & GA & 07-11-11 & 0.61 & & 08-09-12 & 5.17 \\
\hline & 09-28-12 & 2.20 & & $08-17-11$ & 0.63 & & $09-06-12$ & 4.79 \\
\hline \multirow[t]{7}{*}{ BA } & 07-11-11 & 2.96 & & 09-16-11 & 0.61 & PA & 07-07-11 & 1.34 \\
\hline & 07-13-11 & 3.58 & & $07-31-12$ & 0.60 & & $08-12-11$ & 1.19 \\
\hline & 08-17-11 & 3.11 & & $08-22-12$ & 0.52 & & 09-01-11 & 1.01 \\
\hline & $09-13-11$ & 3.01 & GC & $07-07-11$ & 15.7 & & $07-26-12$ & 1.25 \\
\hline & $07-17-12$ & 3.11 & & 08-12-11 & 12.4 & & $08-20-12$ & 1.01 \\
\hline & 08-13-12 & 2.74 & & 09-14-11 & 11.8 & & 09-13-12 & 0.95 \\
\hline & 09-13-12 & 2.57 & & $07-31-12$ & 12.2 & SC & $07-12-11$ & 1.13 \\
\hline \multirow[t]{2}{*}{$\mathrm{BC}$} & 07-08-11 & 17.5 & & $08-20-12$ & 11.6 & & $07-13-11$ & 1.52 \\
\hline & 08-10-11 & 16.1 & & $09-24-12$ & 11.0 & & 08-12-11 & 1.20 \\
\hline \multirow{3}{*}{$\mathrm{BL}$} & 07-31-12 & 5.38 & $\mathrm{HC}$ & $07-20-11$ & 0.39 & & 07-16-12 & 1.24 \\
\hline & $08-22-12$ & 4.24 & & $07-21-11$ & 0.35 & & 08-21-12 & 0.93 \\
\hline & $09-24-12$ & 3.68 & & $08-05-11$ & 0.25 & & 09-05-12 & 0.92 \\
\hline \multirow[t]{6}{*}{$\mathrm{CC}$} & $07-12-11$ & 4.69 & & $08-24-11$ & 0.27 & $\mathrm{SL}$ & 07-11-11 & 1.63 \\
\hline & $08-17-11$ & 4.43 & & 09-02-11 & 0.27 & & 08-17-11 & 1.35 \\
\hline & 09-16-11 & 4.35 & & 09-30-11 & 0.32 & & 09-16-11 & 1.18 \\
\hline & $07-16-12$ & 4.58 & & $07-25-12$ & 0.35 & & $07-17-12$ & 1.27 \\
\hline & 08-13-12 & 3.74 & & 08-08-12 & 0.30 & & 08-16-12 & 1.08 \\
\hline & 09-06-12 & 3.33 & $\mathrm{HE}$ & 07-07-11 & 1.71 & & 09-20-12 & 1.15 \\
\hline \multirow[t]{6}{*}{$\mathrm{CT}$} & $07-07-11$ & 2.99 & & $08-12-11$ & 0.97 & ST & 08-11-11 & 9.49 \\
\hline & $08-17-11$ & 1.06 & & 09-01-11 & 0.89 & & $09-27-11$ & 11.7 \\
\hline & 09-07-11 & 0.80 & & $07-26-12$ & 1.04 & & $07-30-12$ & 8.53 \\
\hline & $07-30-12$ & 1.30 & & 08-20-12 & 0.85 & & 08-28-12 & 7.18 \\
\hline & 08-20-12 & 0.61 & & 09-13-12 & 0.58 & & 09-27-12 & 7.85 \\
\hline & $09-24-12$ & 0.40 & $\mathrm{JJ}$ & $07-29-11$ & 0.24 & WC & 07-07-11 & 0.66 \\
\hline \multirow[t]{6}{*}{$\mathrm{CU}$} & 07-08-11 & 12.2 & & $08-30-11$ & 0.15 & & 07-18-11 & 0.84 \\
\hline & 08-10-11 & 10.5 & & $10-03-11$ & 0.25 & & $08-12-11$ & 0.24 \\
\hline & 09-09-11 & 7.93 & & $07-31-12$ & 0.42 & & 09-07-11 & 0.01 \\
\hline & $07-30-12$ & 1.49 & & $08-22-12$ & 0.21 & & $10-05-11$ & 1.03 \\
\hline & $08-17-12$ & 1.53 & & $09-20-12$ & 0.09 & & 07-13-12 & 0.55 \\
\hline & 09-07-12 & 5.86 & & & & & & \\
\hline
\end{tabular}




\section{Hydrogeologic Framework}

This section provides information on the groundwater system of the Kitsap Peninsula. A brief geologic history of the area is given followed by detailed descriptions of the hydrogeologic units. An understanding of the hydraulic properties of the units and flow of water and water level fluctuations within the aquifers is important to determine the occurrence and availability of groundwater in the study area and to construct a numerical groundwater-flow model.

\section{Geologic Setting}

Many studies have contributed to the current understanding of the geologic history of the study area. Detailed descriptions of the geology in the study area are available in Vaccaro and others (1998) and Jones (1999).

The geology of the Kitsap Peninsula is a complex mix of glacial and nonglacial deposits that subsequently have been influenced by erosion. Four glaciations and three interglaciations are recognized in the Puget Sound lowland. For most of the Puget Sound lowland, the glacial deposits of the Vashon Stade of the Frasier Glaciation (the last major glacial advance) are exposed at the surface.

The ice of the Vashon Stade moved out of Canada about 18,000 years ago and split into two lobes. The Puget lobe flowed south into the Puget Sound lowland, occupied all the lowland, and was about 3,000 ft thick near Seattle and about $6,000 \mathrm{ft}$ thick near the United States-Canada border. The glacier began retreating about 14,500 years ago.

Three types of deposits typically are associated with continental glaciation: advance outwash, till, and recessional outwash. As the glacier flowed south, streams and melting ice at the front of the glacier deposited sediments known as advance outwash. Advance outwash units typically are coarse grained and make good aquifers. As the glacier continued its advance, the advance outwash was covered with glacial till. Glacial till consists of unsorted rocks that range in size from clay to boulders that are picked up by the bottom and sides of the advancing glacier. Till is considered to be a confining unit because of its compaction and resulting poor permeability from the pressure of the thousands of feet of overlying ice. As the glacier began to melt and retreat, streams emanating from the glacier deposited recessional outwash over the top of the till. Like the advance outwash, recessional outwash is coarse grained and typically forms aquifer units.

Each major glacial interval was followed by an extended interglacial period where fluvial, lacustrine, bog, and marsh deposition dominate. Interglacial deposits typically consist of clay, silt, or discontinuous lenses of sand and gravel or peat. Underlying these unconsolidated glacial and interglacial deposits are Tertiary bedrock units consisting primarily of sedimentary claystone, siltstone, sandstone, beds of coal, and volcanic rocks. Since the end of the last glaciation, erosion has been the dominant geomorphic process affecting the peninsula. Alluvial sediments, typically sands and gravels, have been deposited by streams in valleys and marsh deposits formed in low-lying poorly drained areas.

The study area is bisected by a major fault zone running east-west from the southern tip of Bainbridge Island across to the north side of Green and Gold Mountains. On the southern side of the fault zone at the southern end of Bainbridge Island, on the opposite shore north of Manchester and at the entrance to Dyes Inlet, a thick sequence of Tertiary marine sedimentary rock is either exposed at the surface or overlain by glacial deposits (Sceva, 1957). This bedrock unit, known as the Blakely Formation, consists of sandstone, siltstone, claystone, and conglomerate. To the west of Bremerton, at Green and Gold Mountains, the exposed bedrock primarily is basalt.

\section{Hydrogeologic Units}

Hydrogeologic units, consisting of aquifers and confining units (table 4), were defined for this study on the basis of lithologic (depositional facies, grain size, and sorting) and hydrologic (hydraulic conductivity and unit geometry) characteristics. The hydrogeologic units that have been defined previously in Kitsap County by Kahle (1998) for Naval Submarine Base Bangor and subsequently used by Frans and others (2011) as the basis for the hydrogeologic framework of Bainbridge Island are the same units used in this study. The hydrogeologic units used in this study, their correlation with previous studies, and the number of wells used to define the extent and thickness of each unit are shown in table 4.

The surficial geologic units and the deposits at depth were differentiated into aquifers and confining units based on their areal extent and general water-bearing characteristics. Coarse-grained deposits generally have higher permeabilities than fine-grained or poorly sorted deposits. In the Puget Sound lowland, saturated glacial outwash or coarse-grained interglacial deposits form the aquifers, whereas deposits such as till, fine-grained interglacial deposits, or glaciolacustrine deposits form the confining units. Glacial deposits generally are heterogeneous, and although a glacial aquifer may be composed primarily of sand or gravel, it locally may contain varying amounts of clay or silt. Conversely, a confining unit composed predominantly of silt or clay may contain local lenses of coarse material.

The aquifers and confining units identified herein are referred to as hydrogeologic units because the differentiation takes into account the hydraulic and geologic characteristics of the units. Twelve hydrogeologic units were identified in the study area (from youngest to oldest age and generally highest elevation to lowest elevation): 
Table 4. Hydrogeologic unit labels and terminology used in groundwater studies of the Kitsap Peninsula, west-central Washington.

$[-$, not defined]

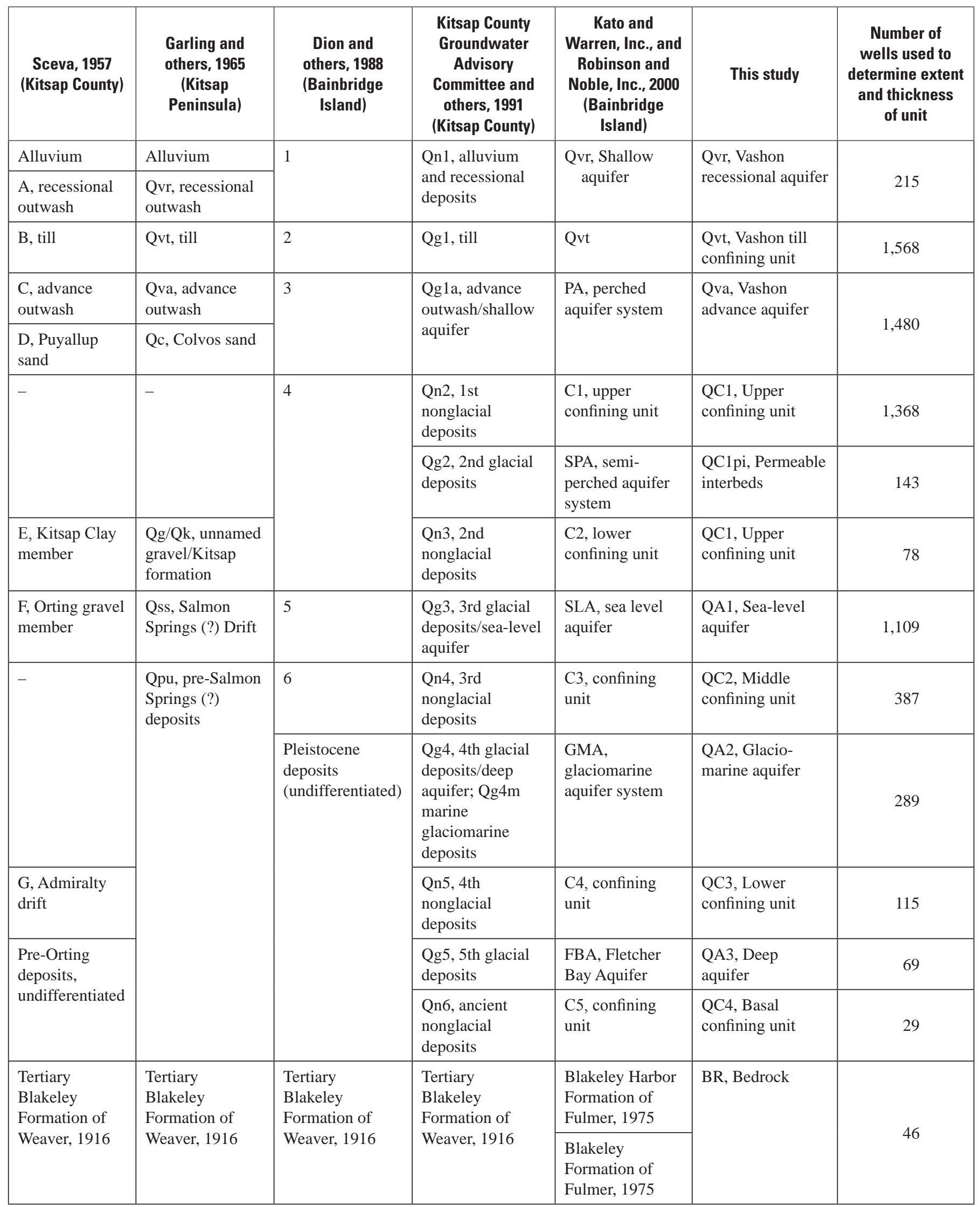


- Vashon recessional aquifer (Qvr),

- Vashon till confining unit (Qvt),

- Vashon advance aquifer (Qva),

- Upper confining unit (QC1),

- Permeable interbeds (QClpi), included locally within QC1,

- Sea-level aquifer (QA1),

- Middle confining unit (QC2),

- Glaciomarine aquifer (QA2),

- Lower confining unit (QC3),

- Deep aquifer (QA3),

- Basal confining unit (QC4), and

- Bedrock (BR).

Previously accepted and published nomenclature associated with the Vashon drift was used for the upper three hydrogeologic units (Qvr, Qvt, and Qva), with Q representing the Quaternary geologic period. Because the deeper geologic units were more variable in terms of grain size and water-bearing characteristics, they were subdivided into hydrogeologic units using names that refer to the type of unit: aquifer (QA) or confining unit (QC), with a number following the letter to indicate the first (1), second (2), or third (3) aquifer, or first (1), second (2), third (3), or fourth (4) confining unit below the Vashon-age deposits. This naming scheme corresponds to that of Kahle (1998) and Frans and others (2011).

A simplified conceptual hydrogeologic model of the groundwater system shows that the system is composed of alternating layers of permeable units (aquifers Qvr, Qva, QClpi, QA1, QA2, and QA3) and less-permeable units (confining units Qvt, QC1, QC2, QC3, and QC4) overlying bedrock (BR). The hydrogeologic units are shown in detail on six hydrogeologic sections (pl. 2). Sections $A-A^{\prime}$ and $B-B^{\prime}$ are oriented south to north and north to south, respectively, and sections $C-C^{\prime}$ through $F-F^{\prime}$ are oriented west to east. Maps showing the areal extent and thickness of units Qvr, Qvt, Qva, QC1, QClpi, QA1, QC2, QA2, QC3, QA3, and QC4 also were prepared (figs. 5-15). Thickness maps were not generated for bedrock (shown on the hydrogeologic sections on plate 2) because of a lack of data from deep-penetrating wells. Depth to the top of bedrock is shown in figure 16 .

All units except Qvr and QC1pi are present throughout most of the study area, although there is considerable variation in thickness of units, as is shown on the hydrogeologic sections (pl. 2). The Vashon till confining unit (Qvt) and the Vashon advance aquifer (Qva) generally are more easily recognized and correlated than older units because of their surface exposures and the numerous wells that penetrate these shallow units. However, all the hydrogeologic units are heterogeneous, resulting in tenuous correlations in many places. Generally, the correlations in the deep units are more indistinct than in shallower units. Many variations in lithology likely occur in the study area at a scale that is too small to be represented explicitly by the constructed hydrogeologic framework. However, these small-scale variations may still influence the availability and movement of groundwater. Local-scale variability in the distribution of glacial depositional facies often results in the formation of spatially discontinuous units of varying thickness; therefore, unit thickness may vary considerably over short distances.

\section{Description of Hydrogeologic Units}

The Vashon recessional aquifer (Qvr) is the youngest unit in the study area and is a discontinuous and thin unconfined aquifer consisting of sand, gravel, and silt, with lenses of silt and clay (fig. 5). Qvr is composed mostly of recessional outwash, but may include younger stream, beach, or landslide deposits. The thickness, calculated from data collected from 215 wells (table 4), ranges from a thin veneer of less than $30 \mathrm{ft}$ to about $120 \mathrm{ft}$, but locally can exceed $120 \mathrm{ft}$ where underlying units are not present. The average thickness is $22 \mathrm{ft}$.

The Vashon till confining unit (Qvt) is present at land surface throughout most of the study area (pls.1 and 2, fig. 6). The till is a dense mix of sand and gravel in a clay matrix and is somewhat discontinuous because of erosion by streams. Some wells are open to water-bearing lenses within Qvt, although yields are relatively small. The unit mantles much of the study area, particularly on hilltops. The thickness of Qvt, calculated from 1,568 wells (table 4), averages $62 \mathrm{ft}$, but varies spatially from a thin veneer to more than $185 \mathrm{ft}$.

The Vashon advance aquifer (Qva) consists of well-sorted sand, or sand and gravel, with lenses of silt and clay that typically underlie the Qvt, but also is exposed at the surface (pls. 1 and 2). Most of the unit is unconfined, but confined groundwater conditions are present where the unit is saturated fully and is overlain by Qvt (fig. 7). The Qva is a widely used aquifer, particularly for domestic uses. The altitude of the top of the unit ranges from near 0 to more than $600 \mathrm{ft}$. The unit generally is absent along the margins of the Kitsap Peninsula and Bainbridge Island likely because of erosion of the unit over time. Qva is not believed to be connected between Bainbridge Island and the Kitsap Peninsula. The thickness of Qva, calculated from data collected from 1,480 wells (table 4), commonly is from 20 to $240 \mathrm{ft}$, with an average thickness of $85 \mathrm{ft}$. In some areas, the thickness exceeds $300 \mathrm{ft}$ owing partly to the inclusion of older sands.

The upper confining unit (QC1) is a thick and laterally extensive low-permeability unit consisting mostly of early Vashon glaciolacustrine silt and clay (Lawton Clay) and underlying interglacial deposits of silt, sand, and gravel with numerous lenses of silt and clay or silty peat. In some locations of the study area, there are thin and discontinuous lenses of till and outwash sand. The top of QC1 ranges from $80 \mathrm{ft}$ below sea level to more than $500 \mathrm{ft}$ (pl. 2). The thickness, calculated from data collected from 1,368 wells (table 4), ranges from 50 to $300 \mathrm{ft}$ with an average thickness of $128 \mathrm{ft}$, but can exceed $300 \mathrm{ft}$ in places (fig. 8). The unit is widespread throughout the study area, but is locally absent in small areas on Bainbridge Island, near Gig Harbor, and where bedrock outcrops on the surface. 


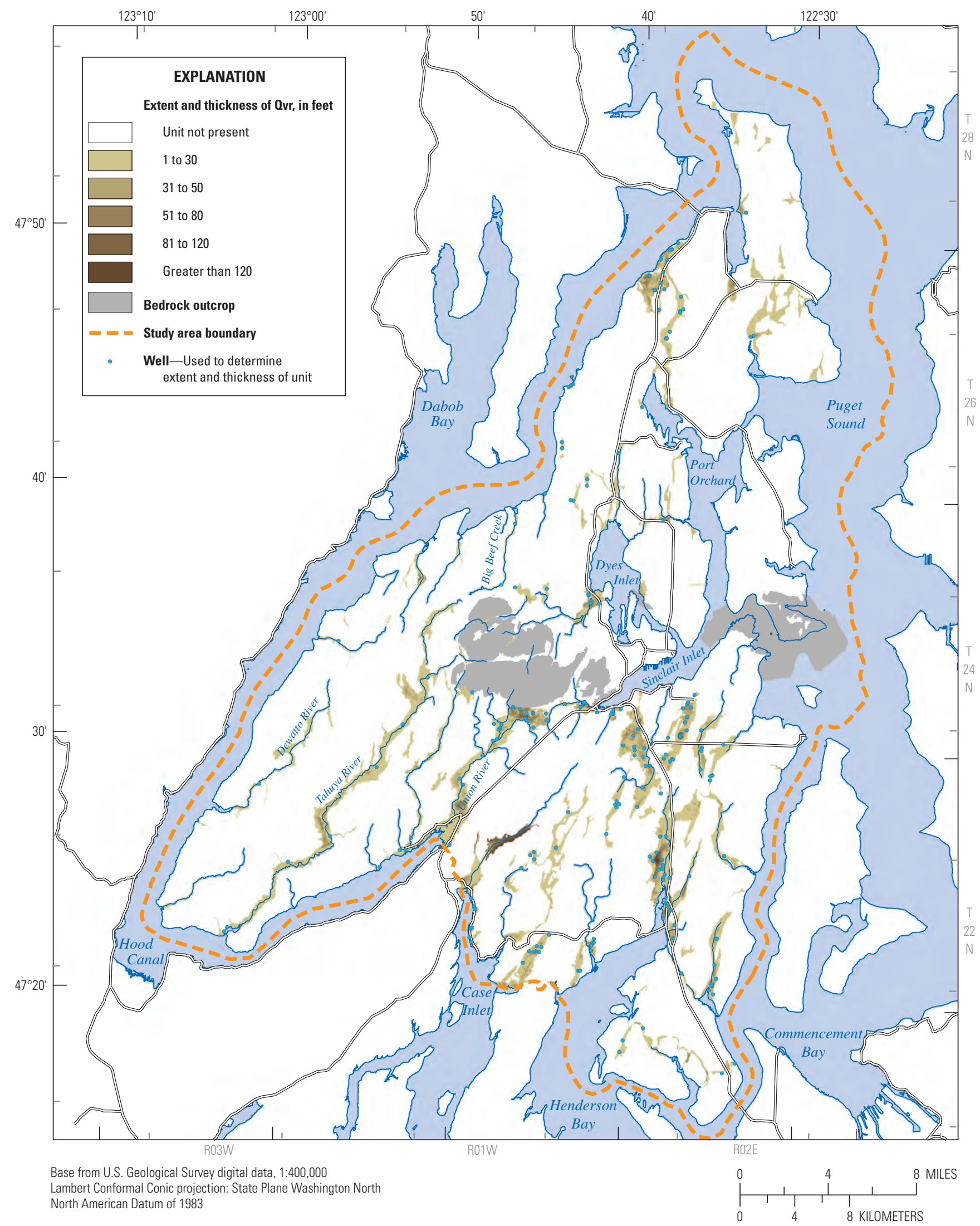

Figure 5. Extent and thickness of Vashon recessional aquifer (Qvr), Kitsap Peninsula, west-central Washington. 


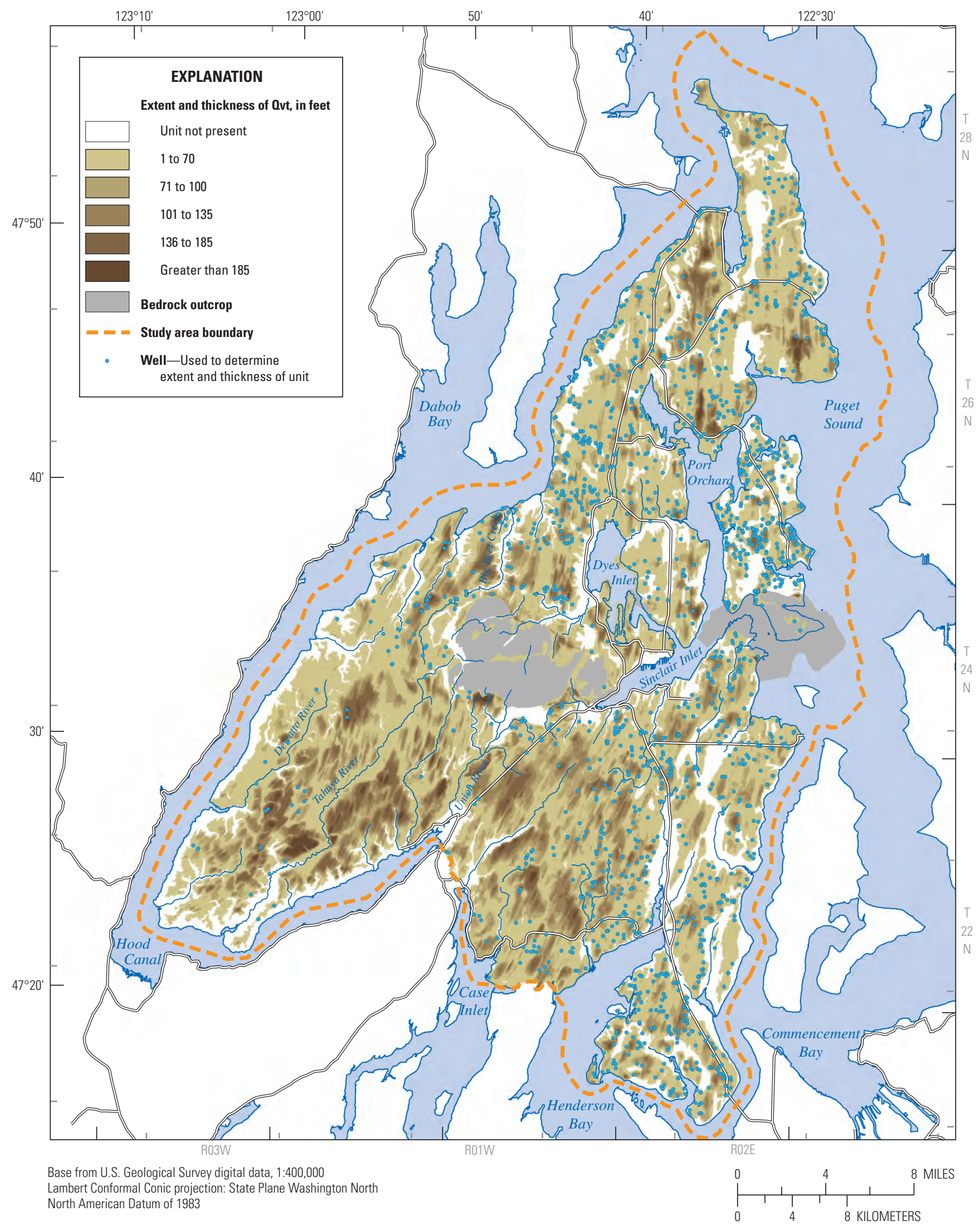

Figure 6. Extent and thickness of Vashon till confining unit (Qvt), Kitsap Peninsula, west-central Washington. 


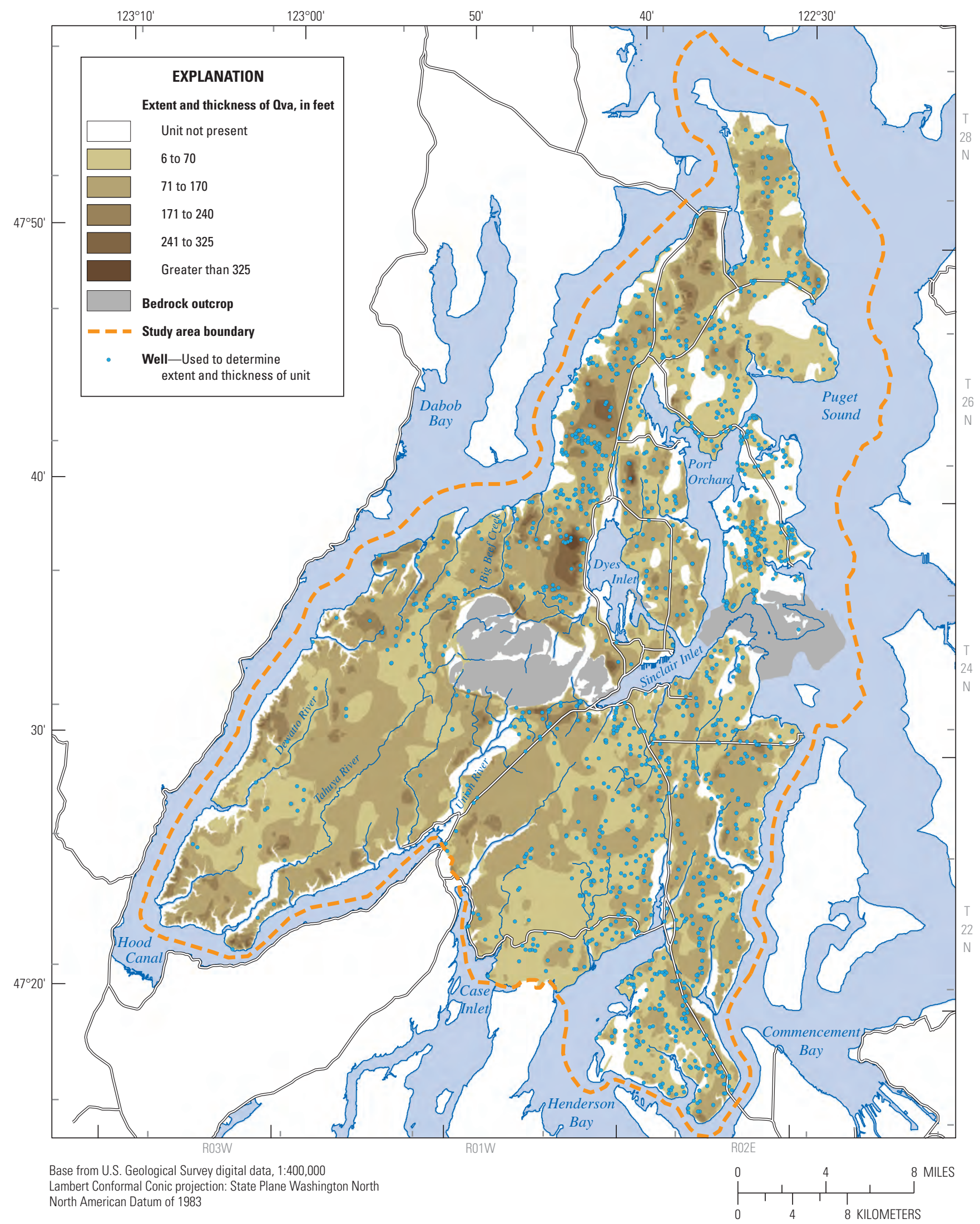

Figure 7. Extent and thickness of Vashon advance aquifer (Qva), Kitsap Peninsula, west-central Washington. 


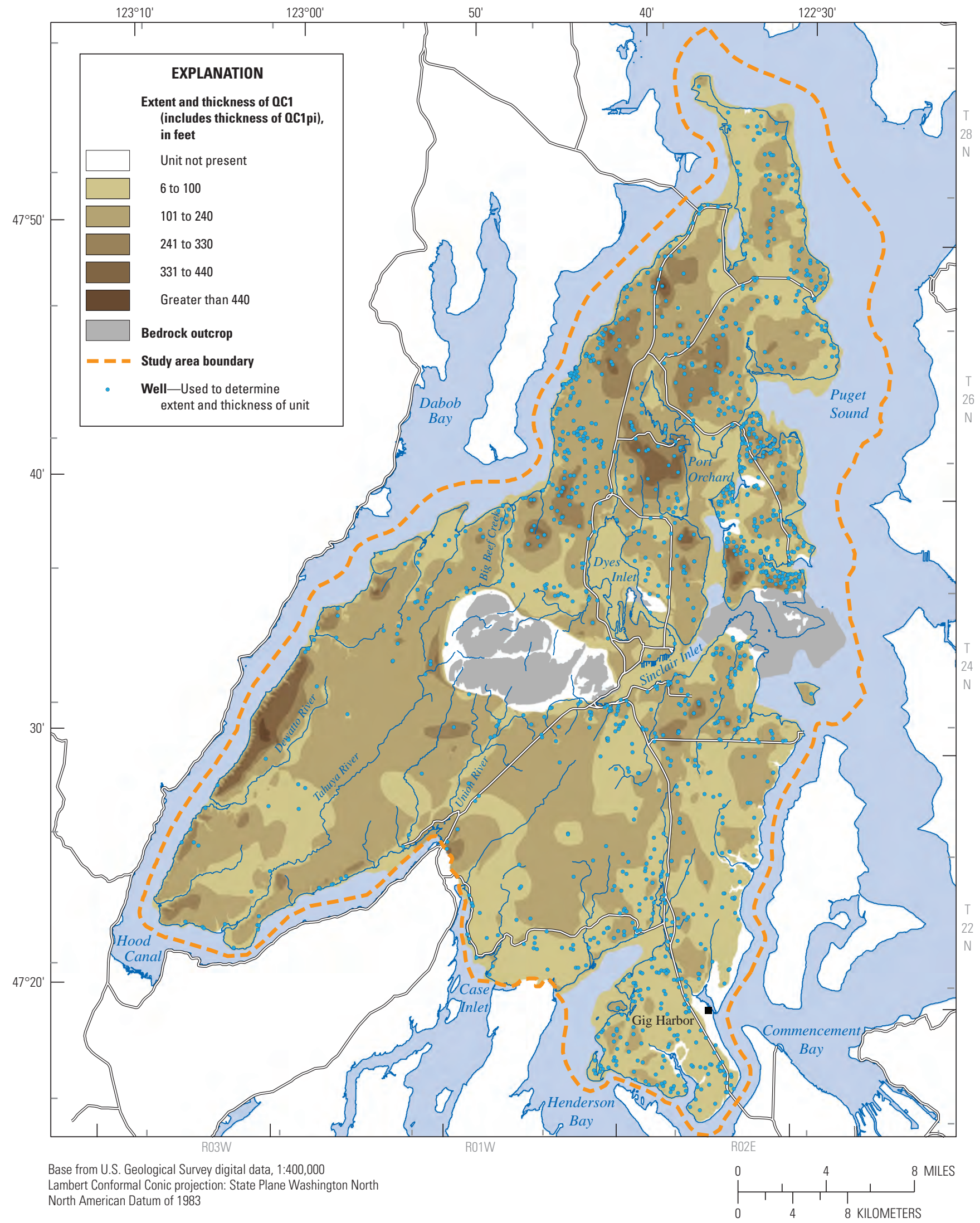

Figure 8. Extent and thickness of the upper confining unit (OC1), Kitsap Peninsula, west-central Washington. 
Locally continuous and mappable zones of sand and gravel within the upper confining unit are referred to as the permeable interbeds (QClpi). These interbeds were identified using 143 wells and where data were sufficient to recognize and correlate the unit. The thickness generally ranges from 10 to $50 \mathrm{ft}$. Although the permeable interbeds commonly are mapped as isolated lenses of coarse-grained material (fig. 9), Kahle (1998) hypothesized that the deposits constituting the unit may be part of a complicated system of braided channels, and as such, the unit may extend from sea level to more than $200 \mathrm{ft}$ above sea level (pl. 1). The permeable interbeds previously have been called the semi-perched aquifer (Kato and Warren, Inc., and Robinson and Noble, Inc., 2000) and are primarily north and west of Port Orchard; however, small areas have been mapped on Bainbridge Island (Frans and others, 2011).

The sea-level aquifer (QA1) is extensive, widely used, and mostly confined by QC1. It is generally confined, but is exposed at land surface along some areas of the coastline (fig. 10). QA1 consists primarily of glacial sand and gravel, with silt interbeds. The top of QA1 ranges from several hundred feet below sea level to more than $300 \mathrm{ft}$ above sea level, with the average being around $20 \mathrm{ft}$ (pls. 1 and 2). The sea-level aquifer is believed to extend from Bainbridge Island and beneath Agate Passage to the Kitsap Peninsula because of the narrow and shallow nature of the passage and the depths at which the QA1 unit occurs in this area. The average thickness, calculated from data collected from 1,109 wells (table 4), is $84 \mathrm{ft}$, but typical thickness ranges from 50 to $250 \mathrm{ft}$.

The middle confining unit (QC2) is a low-permeability unit consisting of interglacial sandy silty clay and glacial sand and gravel, with significant amounts of silt and clay layers. QC2 is present throughout the study area (fig. 11), except on the southern end of Bainbridge Island and around other areas where bedrock is near the surface. The middle confining unit is shown as absent in two other localized areas where data from well logs were sufficient to delineate its extent. The top of the unit ranges from about $200 \mathrm{ft}$ above sea level to more than $500 \mathrm{ft}$ below sea level (pl. 2). Based on data from 387 wells, QC2 commonly is 100-300 ft thick, but thicknesses greater than $600 \mathrm{ft}$ are present on Bainbridge Island in a few locations (fig. 11). Some of the areas where QC2 is thick occur where QA2 is absent. Thus, where QA2 is absent, some of the thickness mapped as QC2 may actually be QC3 because QC2 and QC3 are indistinguishable in such areas.

The glaciomarine aquifer (QA2) is a confined aquifer ranging in composition from sand and gravel to silt. Shell fragments have been noted in this unit in some areashence, its marine name. Few wells withdraw water from this aquifer because of its depth and generally lower permeability compared to Qva and QA1. On the basis of the limited well data for this unit (289 wells), thicknesses range from less than 20 to more than $300 \mathrm{ft}$. The average thickness is about $85 \mathrm{ft}$. The glaciomarine aquifer unit generally is thicker on Bainbridge Island and along the southern end of Sinclair Inlet. The glaciomarine aquifer unit is absent locally in areas on the northern end of Bainbridge Island and at the southern end of Bainbridge Island and other parts of the study area where it intersects bedrock below land surface or bedrock is present at the surface (fig. 12). The glaciomarine aquifer unit is thought to extend beneath Port Orchard because well logs indicate its presence on both Bainbridge Island and the Kitsap Peninsula. Port Orchard is shallow, and it is not likely that the channel was carved to the depth required to erode the QA2 unit. The top of QA2 ranges from more than $600 \mathrm{ft}$ below sea level to less than $200 \mathrm{ft}$ below sea level (pl. 2).

The lower confining unit (QC3) is a low-permeability unit composed of clay and silt, with some gravel, and is extensive laterally. QC3 is absent where it intersects bedrock below land surface or when bedrock is present at the surface (fig. 13). The top of the lower confining unit ranges from more than $800 \mathrm{ft}$ below sea level to slightly less than sea level (pl. 2). Limited well data from 115 wells indicate that the thickness of the unit ranges from less than $50 \mathrm{ft}$ to more than $500 \mathrm{ft}$, with an average thickness of $193 \mathrm{ft}$ (fig. 13). As was the case with QC2, some part of QC4 likely is included in the reported thickness of this unit where QA3 is absent.

The deep aquifer (QA3) is laterally extensive and confined. The aquifer is locally absent in areas on Bainbridge Island and in other parts of the study area where it intersects bedrock below land surface or bedrock is present at the surface (fig. 14). QA3 consists mostly of sand and gravel with silt interbeds. The top of the deep aquifer ranges from more than $900 \mathrm{ft}$ below sea level to slightly more than $200 \mathrm{ft}$ below sea level (pl. 2). Typical thicknesses, calculated from data collected from 69 wells, are from 50 to $350 \mathrm{ft}$, with an average thickness of $128 \mathrm{ft}$; however, thicknesses are greater than $300 \mathrm{ft}$ in parts of the north-central area of Bainbridge Island and on the south side of Sinclair Inlet (fig. 14). As with the QA2 unit, QA3 is thought to extend beneath Port Orchard.

The basal confining unit (QC4) is a low-permeability unit composed of clay and silt with some gravel, and is extensive laterally. It is not present on the southern end of Bainbridge Island or in other parts of the study area where it intersects bedrock below land surface or bedrock is present at the surface (fig. 15). The top of the basal confining unit ranges from more than $1,200 \mathrm{ft}$ below sea level to slightly less than $500 \mathrm{ft}$ below sea level (pl. 2). The thickness estimates of this unit were computed by subtracting the top of bedrock from the top of QC4; therefore, thickness values are relatively large and can exceed $1,000 \mathrm{ft}$.

Bedrock (BR) is present beneath the entire study area and at land surface (fig. 16 and pls. 1 and 2). Bedrock consists largely of marine and non-marine sedimentary rocks and volcanic rocks. Bedrock is at or near the surface on the southern end of Bainbridge Island and west of Bremerton at Green and Gold Mountains. The depth to the top of bedrock was computed by subtracting the top altitude of bedrock from the land surface DEM. Estimated thicknesses of the unconsolidated sediments above bedrock in the study area range from $0 \mathrm{ft}$ where bedrock is present at land surface to more than 2,000 ft in the northern part of the study area. 


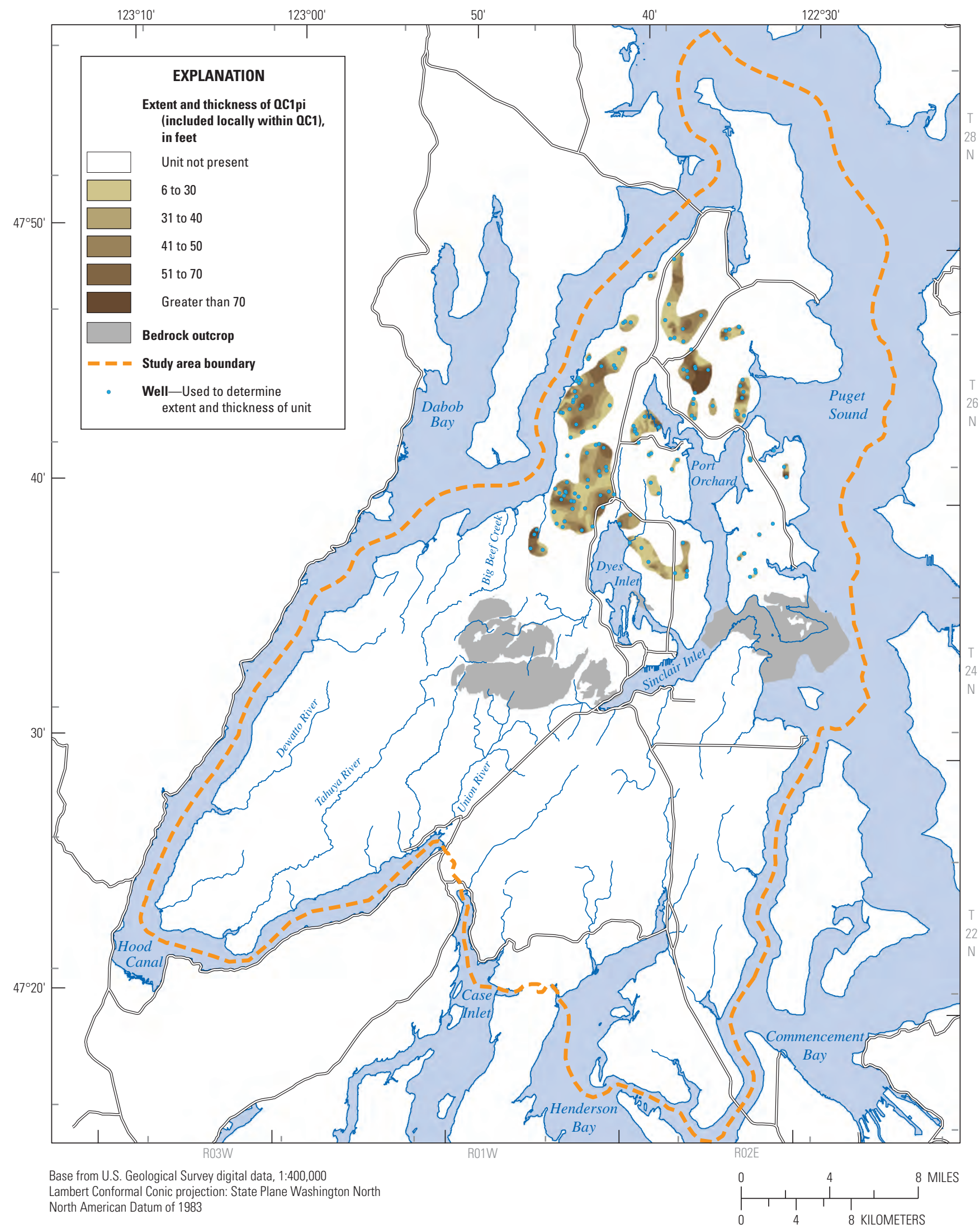

Figure 9. Extent and thickness of the permeable interbeds (0C1pi), Kitsap Peninsula, west-central Washington. 


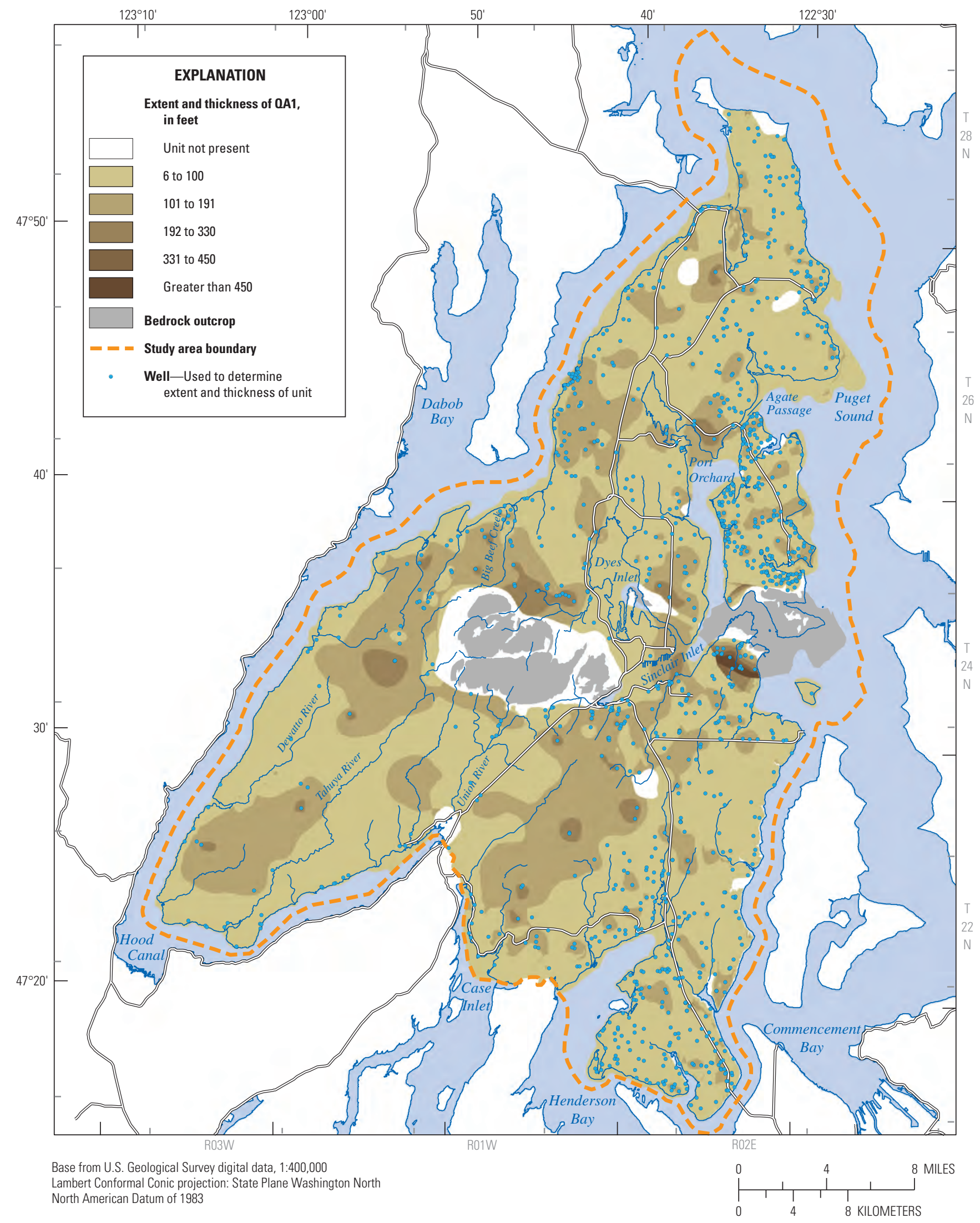

Figure 10. Extent and thickness of the sea-level aquifer (OA1), Kitsap Peninsula, west-central Washington. 


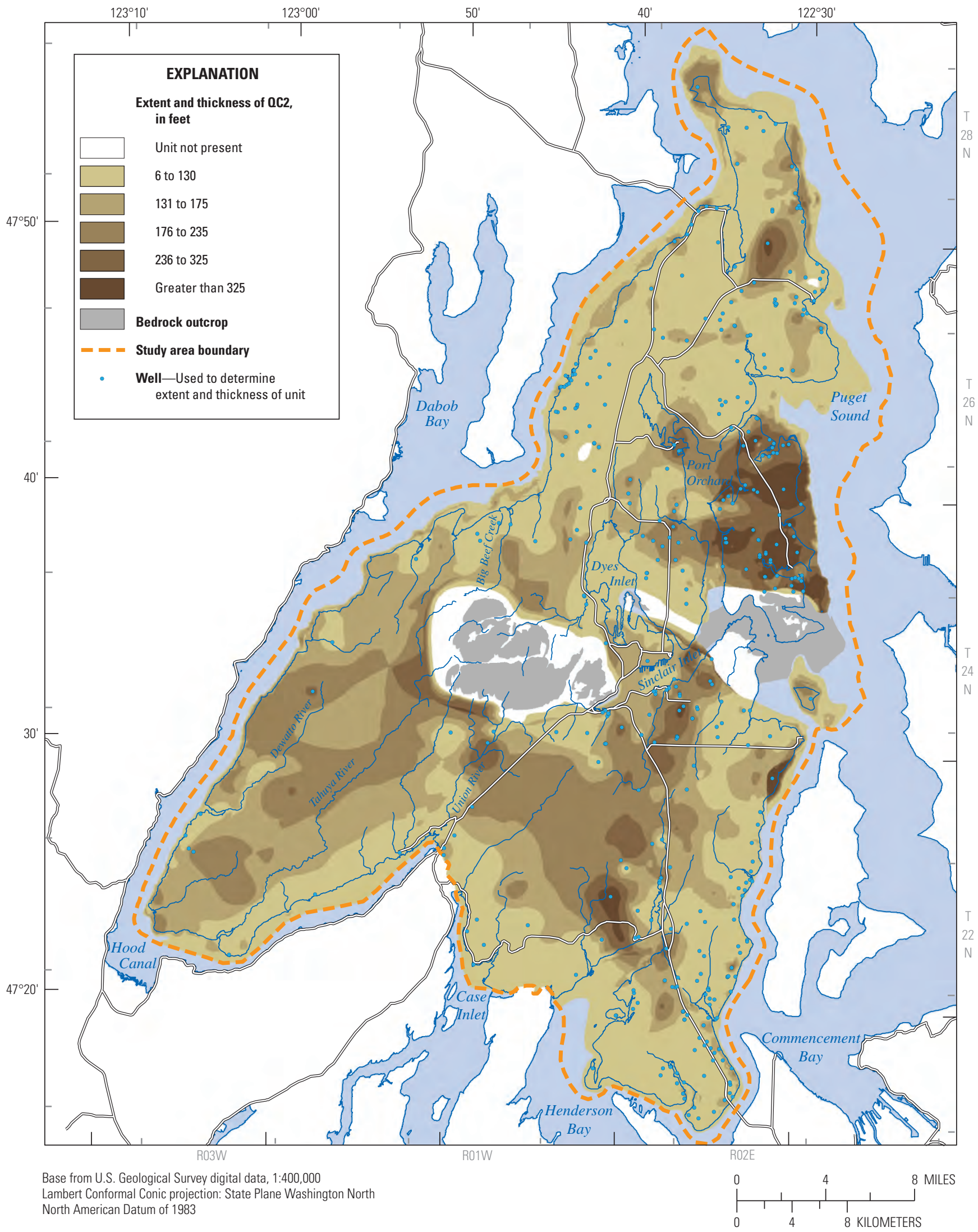

Figure 11. Extent and thickness of the middle confining unit (QC2), Kitsap Peninsula, west-central Washington. 


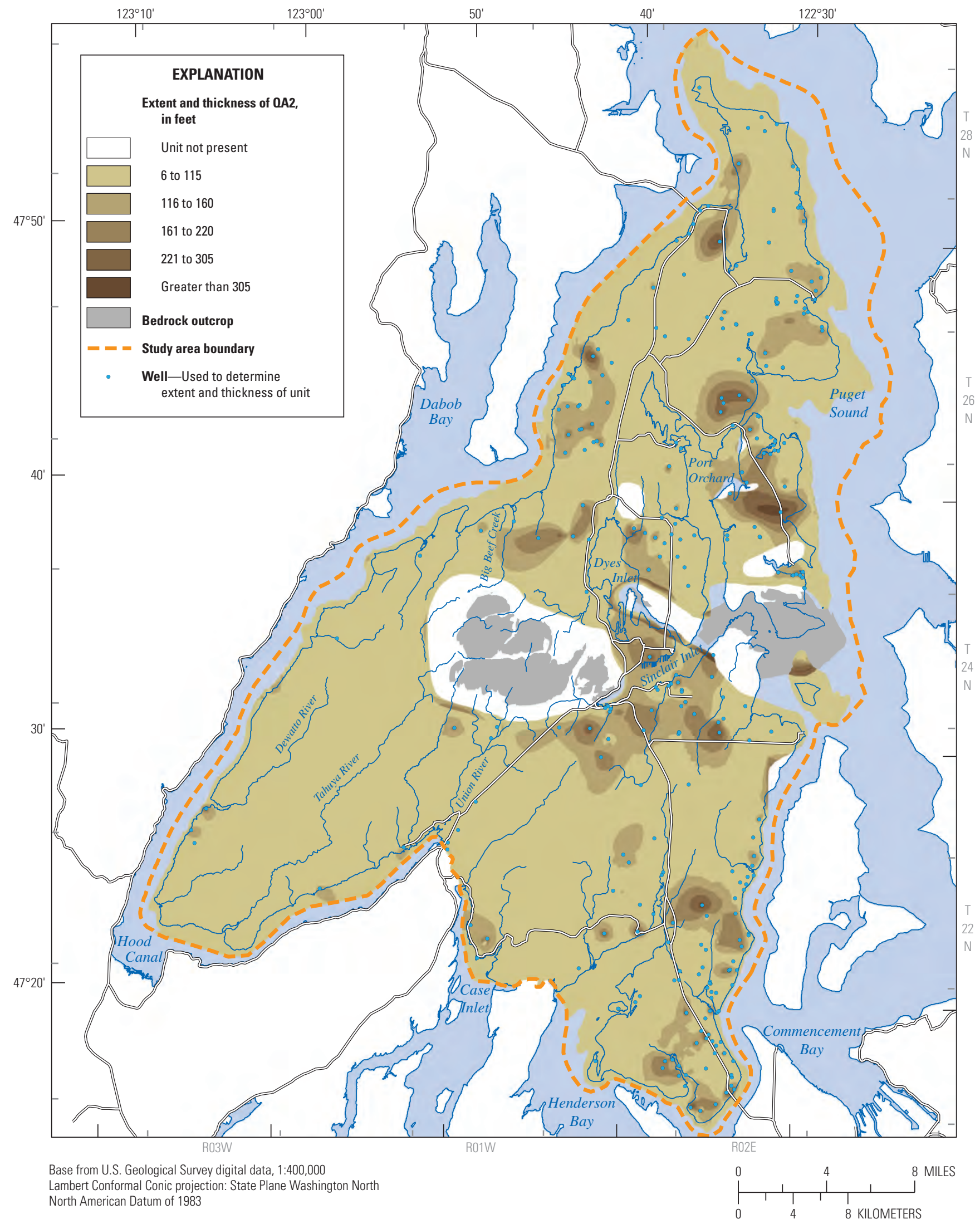

Figure 12. Extent and thickness of the glaciomarine aquifer ( $Q A 2)$, Kitsap Peninsula, west-central Washington. 


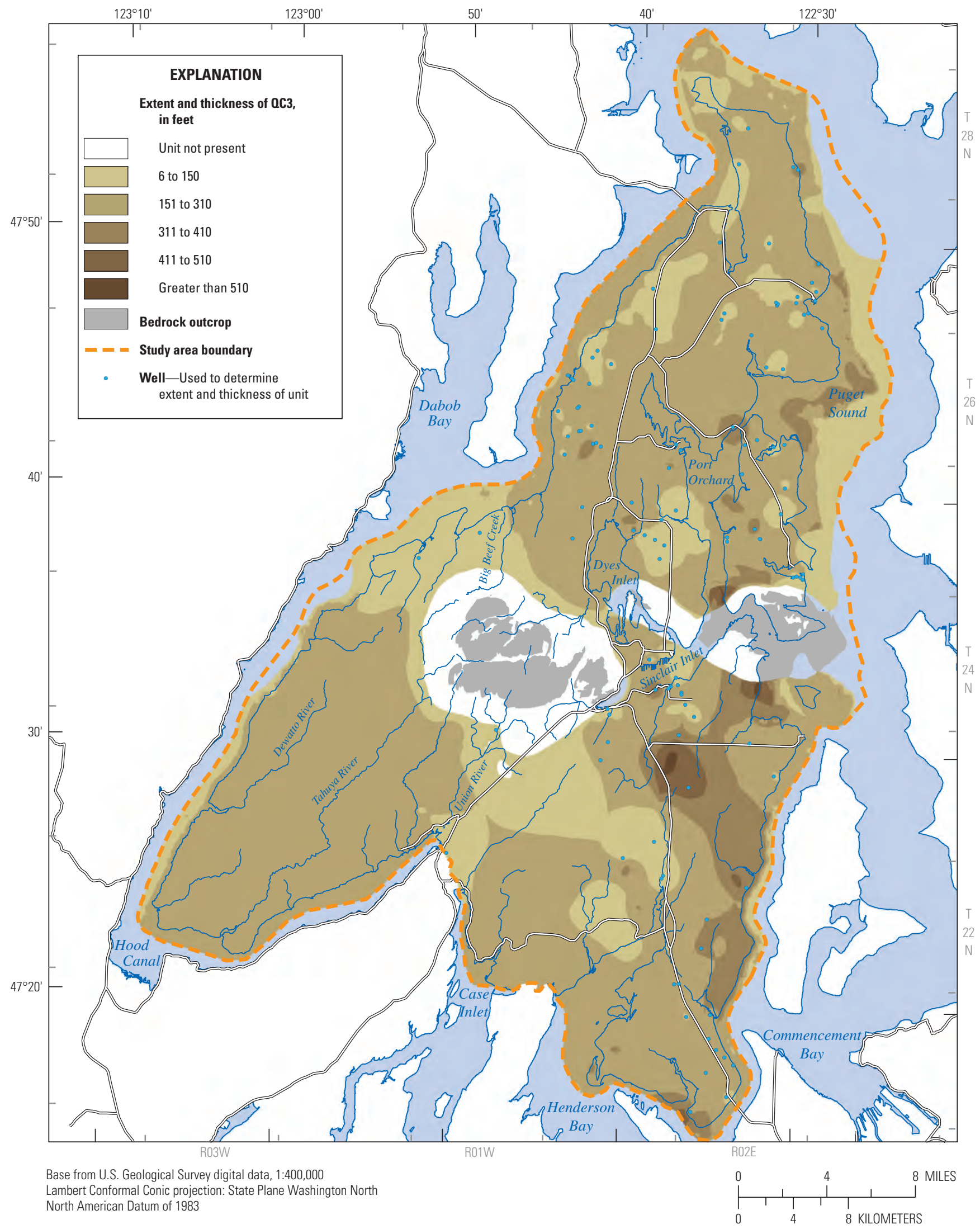

Figure 13. Extent and thickness of the lower confining unit (OC3), Kitsap Peninsula, west-central Washington. 


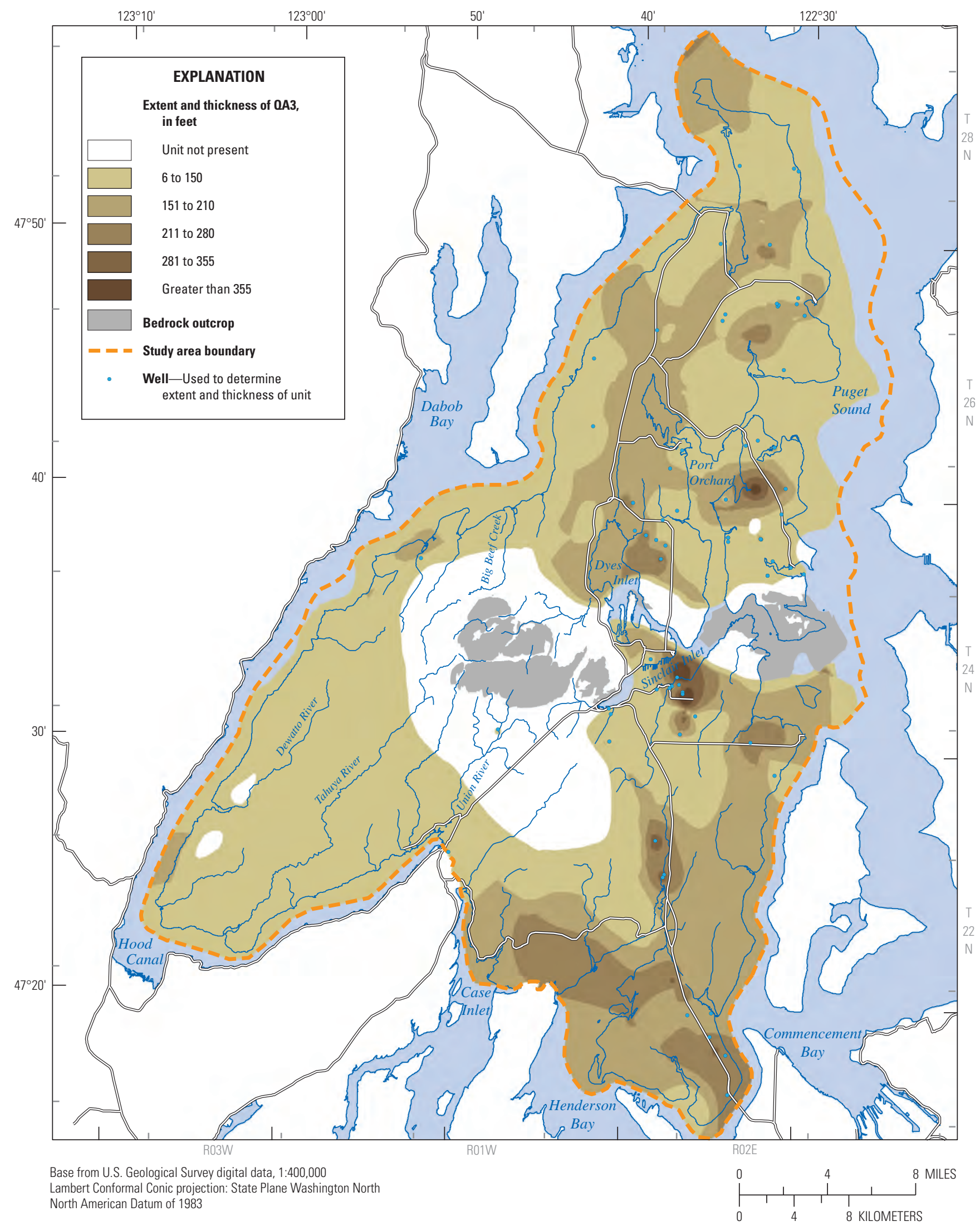

Figure 14. Extent and thickness of the deep aquifer (QA3), Kitsap Peninsula, west-central Washington. 


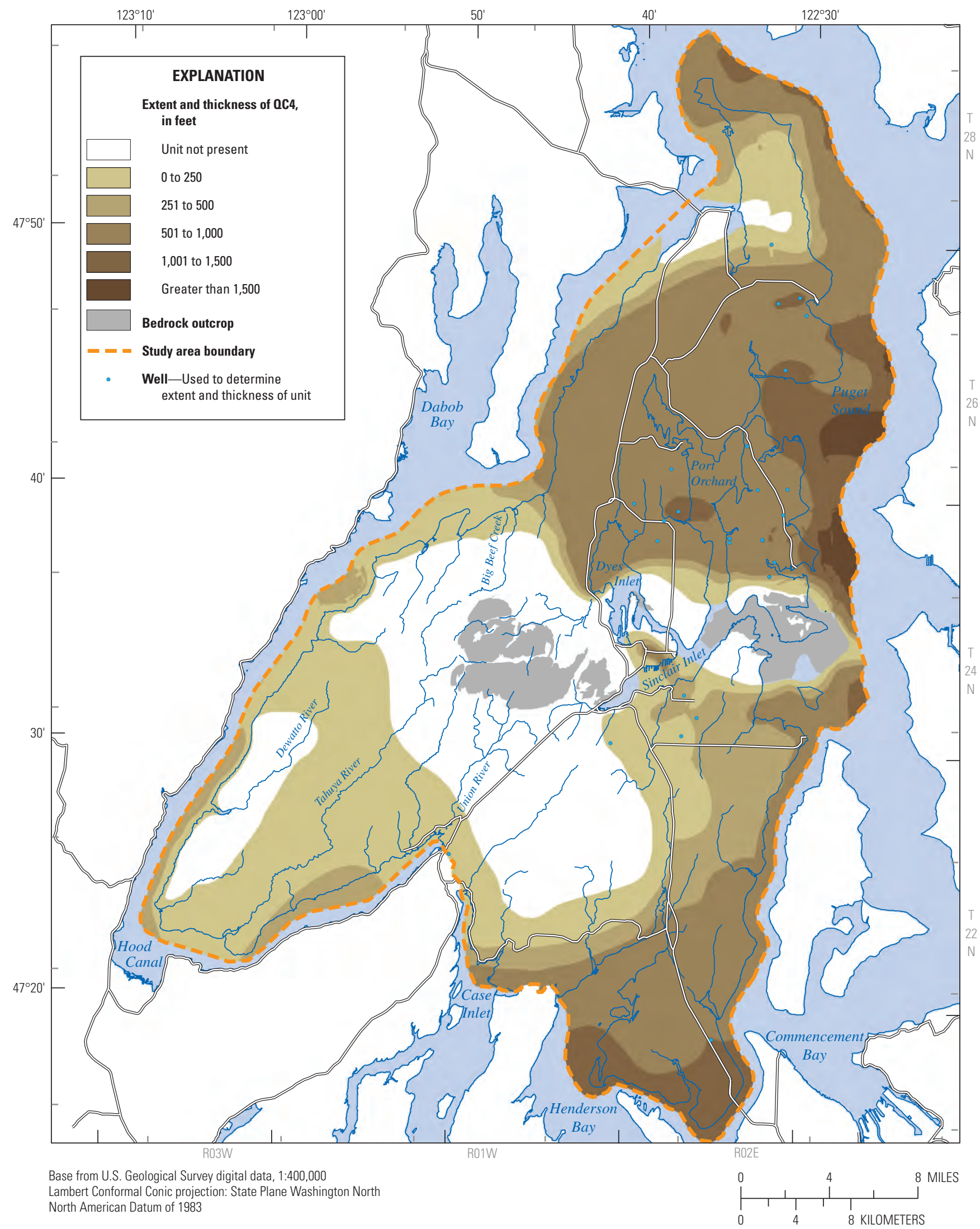

Figure 15. Extent and thickness of the basal confining unit (OC4), Kitsap Peninsula, west-central Washington. 


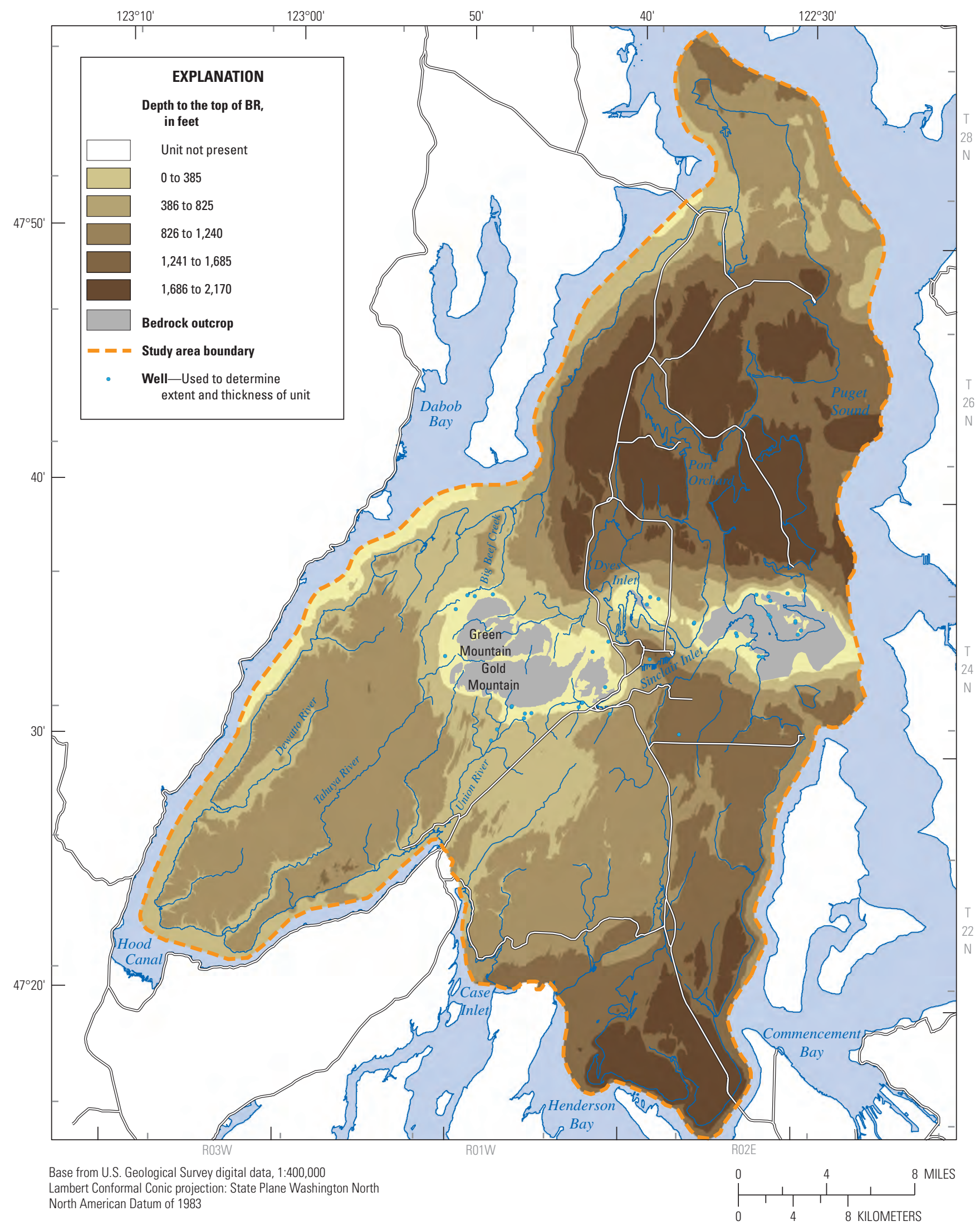

Figure 16. Extent and depth to the top of the bedrock unit (BR), Kitsap Peninsula, west-central Washington. 


\section{Hydraulic Properties of Hydrogeologic Units}

Horizontal hydraulic conductivities of the hydrogeologic units initially were estimated from specific-capacity data obtained from drillers' logs of the study wells (discharge rate, discharge time, drawdown, well-construction data, and lithology). The specific-capacity data were converted to hydraulic conductivity using one of two equations, depending on the construction method used for the well. Only data from wells with complete specific-capacity information were used.

For wells that had a screened or perforated interval, the modified Theis equation (Ferris and others, 1962) was used to estimate transmissivity values. This equation, solved for transmissivity using an iterative method, is

$$
T=\frac{Q}{4 \pi s} \ln \frac{2.25 T t}{r^{2} S}
$$

where

$T$ is transmissivity of the hydrogeologic unit, in feet squared per day;

$Q$ is discharge, or pumping rate, of the well, in cubic feet per day;

$s$ is drawdown in the well, in feet;

$t$ is length of time the well was pumped, in days;

$r$ is radius of the well, in feet; and

$S$ is storage coefficient, dimensionless, assumed to be 0.0001 as the units generally are confined.

Assumptions for using equation 1 are that

1. aquifers are homogeneous, isotropic, and infinite in extent;

2. wells fully penetrate the aquifer;

3. flow to the well is horizontal; and

4. water is released from storage instantaneously.

Leakage from adjoining units was not considered to be a factor. Although most of the assumptions are not met precisely, the field conditions in the study area approximate most of the assumptions and the calculated horizontal hydraulic conductivities are reasonable.

Horizontal hydraulic conductivity was computed using the transmissivity from equation 1 and the following equation:

$$
K_{h}=\frac{T}{b}
$$

where

$$
\begin{aligned}
& K_{h} \text { is horizontal hydraulic conductivity of the } \\
& \text { hydrogeologic unit, in feet per day; } \\
& T \text { is transmissivity, as calculated using } \\
& \text { equation 1; and } \\
& b \text { is thickness of the hydrogeologic unit, in feet, } \\
& \text { approximated by the length of the open } \\
& \text { interval as described in the drillers' water } \\
& \text { well report. }
\end{aligned}
$$

The use of the open interval to approximate the thickness of a hydrogeologic unit assumes that the wells are open through the entire thickness of the unit, which was never the case. Nevertheless, this assumption is necessary because the equations assume only horizontal flow. In a homogeneous hydrogeologic unit, horizontal flow can be measured only if a well penetrates the entire unit thickness. However, in heterogeneous and anisotropic glacial hydrogeologic units, such as those in the study area, vertical flow likely is much smaller than horizontal flow because the layering of the geologic materials leads to horizontal hydraulic conductivities that generally are much larger than vertical hydraulic conductivities. Thus, the assumption that the open interval represents the local thickness of the hydrogeologic unit is considered reasonable.

A second equation was used to estimate horizontal hydraulic conductivity for wells with no screen or perforations, but only an open end, and no vertical dimension to the opening. Bear (1979) provides an equation for hemispherical flow to an open-ended well that just penetrates the upper part of an aquifer. When modified for spherical flow to an open-ended well within an aquifer, the equation becomes

$$
K_{h}=\frac{Q}{4 \pi s r}
$$

where

$$
\begin{aligned}
& K_{h} \text { is horizontal hydraulic conductivity of the } \\
& \text { hydrogeologic unit, in feet per day; } \\
& Q \text { is discharge, or pumping rate of the well, in } \\
& \text { cubic feet per day; } \\
& S \text { is drawdown in the well, in feet; and } \\
& r \text { is radius of the well, in feet. }
\end{aligned}
$$


Equation 3 is based on the assumption that groundwater can flow at the same rate in all directions, and specifically that horizontal and vertical hydraulic conductivities are equal. This is not likely to be true for glacial material. However, the errors associated with disregarding this assumption are likely to be less than errors resulting from using equations 1 and 2 for open-ended wells.

The median hydraulic conductivities estimated for hydrogeologic units in this study are biased toward higher values because of the nature of the statistical sample of inventoried wells. The ideal statistical sample of wells would represent all the horizontal and vertical variations of lithology and pore-size structure in the hydrogeologic units. The wells used in this study represent only the more productive parts of the units because they primarily are domestic wells that were drilled for water-supply purposes. Generally, when a driller installs a well, the depth, location, and construction of the well are determined to maximize the amount of water that can be pumped. Thus, the less productive fine-grained parts of the hydrogeologic units are bypassed until a coarse-grained productive part is found.
The bias toward higher values of hydraulic conductivity is more acute for the confining units than for the aquifers.

Horizontal hydraulic conductivities were calculated for wells with available data, and statistical summaries were prepared by hydrogeologic unit (table 5). The estimated median hydraulic conductivities for the aquifers (Qva, $51 \mathrm{ft} / \mathrm{d}$; QC1pi, $27 \mathrm{ft} / \mathrm{d}$; QA1, $38 \mathrm{ft} / \mathrm{d}$; QA2, $35 \mathrm{ft} / \mathrm{d}$; and QA3, $32 \mathrm{ft} / \mathrm{d}$ [table 5]) are similar in magnitude to values reported by Freeze and Cherry (1979) for similar materials. The estimated median hydraulic conductivity for the bedrock unit ( $2.3 \mathrm{ft} / \mathrm{d}$ ) is higher than is typical for most of the material in these units because of the bias toward higher values.

Estimates of horizontal hydraulic conductivity also were compiled from aquifer tests conducted by environmental consulting firms, and statistical summaries of these data were prepared according to hydrogeologic unit (table 5). Aquifer test data were available for public-supply wells only and are biased toward the major water-producing aquifers in the study area. Hydraulic conductivity information can be used to help constrain numerical flow model calibrations.

Table 5. Summary of horizontal hydraulic conductivities estimated from specificcapacity data and aquifer tests, by hydrogeologic unit, Kitsap Peninsula, west-central Washington.

\begin{tabular}{|c|c|c|c|c|}
\hline \multirow{2}{*}{ Hydrogeologic unit } & \multirow{2}{*}{$\begin{array}{l}\text { Number } \\
\text { of wells }\end{array}$} & \multicolumn{3}{|c|}{ Hydraulic conductivity (feet per day) } \\
\hline & & Minimum & Median & Maximum \\
\hline \multicolumn{5}{|c|}{ Estimated from specific-capacity data } \\
\hline Qva, Vashon advance aquifer & 335 & 0.335 & 51 & 3,527 \\
\hline QC1pi, permeable interbeds & 62 & 0.35 & 27 & 663 \\
\hline QA1, sea-level aquifer & 395 & 0.2 & 38 & 6,111 \\
\hline QA2, glaciomarine aquifer & 82 & 0.18 & 35 & 1,661 \\
\hline QA3, deep aquifer & 22 & 0.75 & 32 & 1,993 \\
\hline BR, bedrock & 6 & 0.004 & 2.3 & 158 \\
\hline \multicolumn{5}{|c|}{ Estimated from aquifer tests } \\
\hline Qva, Vashon advance aquifer & 11 & 10 & 94 & 2,339 \\
\hline QC1pi, permeable interbeds & 4 & 91 & 181 & 334 \\
\hline QA1, sea-level aquifer & 30 & 2 & 64 & 891 \\
\hline QA2, glaciomarine aquifer & 28 & 8 & 72 & 602 \\
\hline QA3, deep aquifer & 14 & 6 & 42 & 2,406 \\
\hline
\end{tabular}




\section{Groundwater Movement}

This section describes the movement of groundwater in the aquifer system in the study area, and includes discussions of groundwater recharge, flow direction, discharge to surface water, exchange of water between the aquifer system and streams, and temporal fluctuations in groundwater levels. The processes of groundwater movement occur within the physical domain described by the hydrogeologic framework and are influenced by the hydrogeologic characteristics of the aquifer system in which they occur, and by other factors, including streamflow, the spatial distribution of precipitation, and land cover.

\section{Recharge}

Most of the recharge to the groundwater system is in the form of deep percolation of precipitation. Secondary recharge also occurs as the result of septic-system and irrigation return flows. Precipitation is the dominant source of water recharging the groundwater-flow system in the study area, and it is reasonable to expect groundwater recharge to vary with precipitation. Factors such as the permeability of surficial soils, the hydrogeologic units they formed on, and the hydrogeologic units and land-cover characteristics also affect recharge; therefore, the relation between precipitation and recharge also likely depends on soils and landcover characteristics. The distribution of recharge from precipitation in the study area was estimated by applying precipitation-recharge regression equations (developed for areas in Washington State by Bidlake and Payne [2001]) that incorporate the effects of surficial characteristics.

Annual precipitation amounts were from the Parameterelevation Regressions on Independent Slopes model (PRISM) (PRISM Climate Group, 2012) for 1985-90. For 1991-2012, precipitation data were available from a network of KPUD operated weather stations that provided greater spatial resolution of precipitation data than PRISM (Martin Sebren, Kitsap Public Utility District, written commun., 2013). The KPUD precipitation data were converted to a grid by interpolating between the locations of the precipitation stations using a method based on the ANUDEM procedure developed by Hutchinson (1989).

The effects of soils on recharge from precipitation (fig. 17) were estimated using regression equations developed by Bidlake and Payne (2001) for soils in western Washington. Soil data were generalized from the Soil Survey Geographic (SSURGO) soils dataset (U.S. Department of Agriculture, 2004). Soil data were not available for the Bangor naval base; therefore, hydrogeology data were used at that location. Recharge was estimated for soils formed on aquifer units (outwash and alluvium) exposed at land surface in the study area using one regression equation, and recharge was estimated for soils formed on till and fine-grained sediments using a second regression equation. Recharge estimates for areas where bedrock is exposed at land surface required the approximation

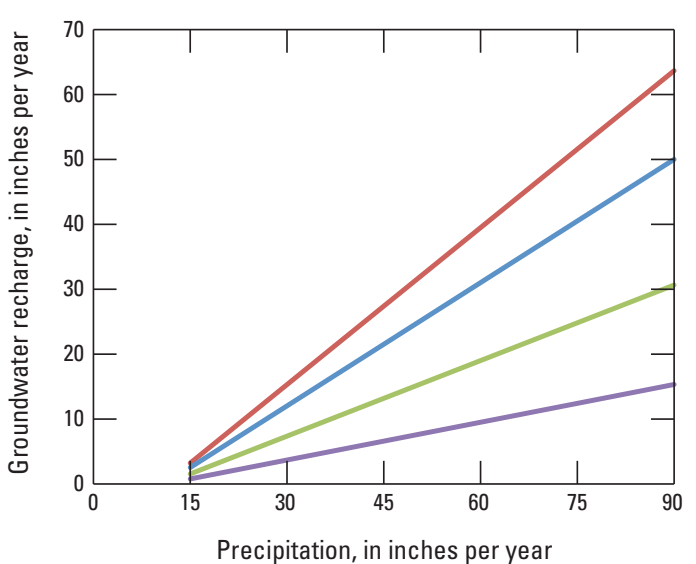

\section{EXPLANATION}

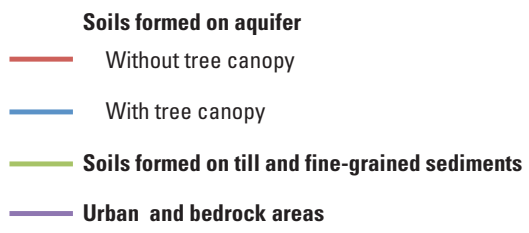

Figure 17. Precipitation-groundwater recharge relations and effects of land cover, Kitsap Peninsula, west-central Washington.

of an additional precipitation-recharge equation for this study. Savoca and others (2009) developed a precipitation-recharge estimate for bedrock that was used for this study. Recharge characteristics of the bedrock unit were estimated to be one-half the recharge of the unconsolidated confining units.

The equations from Bidlake and Payne (2001) account for the effect of evaporative losses from the interception of precipitation by tree canopy (fig. 17). Tree canopy distribution data were obtained from the National Land Cover Database (Fry and others, 2011). If the landcover classification was coded as mixed, evergreen, or deciduous forest, the forest vegetation regression equation was used. Areas coded as grasslands, open space, shrubs, or low-intensity developed land used the non-forest vegetation equation. If the land-cover data were coded as areas of medium- and high-density development, which have impervious areas, or barren land, the urban land regression equation was used. No direct recharge from precipitation was assumed for areas covered by water such as lakes or wetlands.

GIS techniques were used to combine the landcover data with precipitation to calculate the distribution of groundwater recharge from precipitation in the study area for each year between 1985 and 2012, as well as for the PRISM 30-year average for 1980-2010 (fig. 18). 


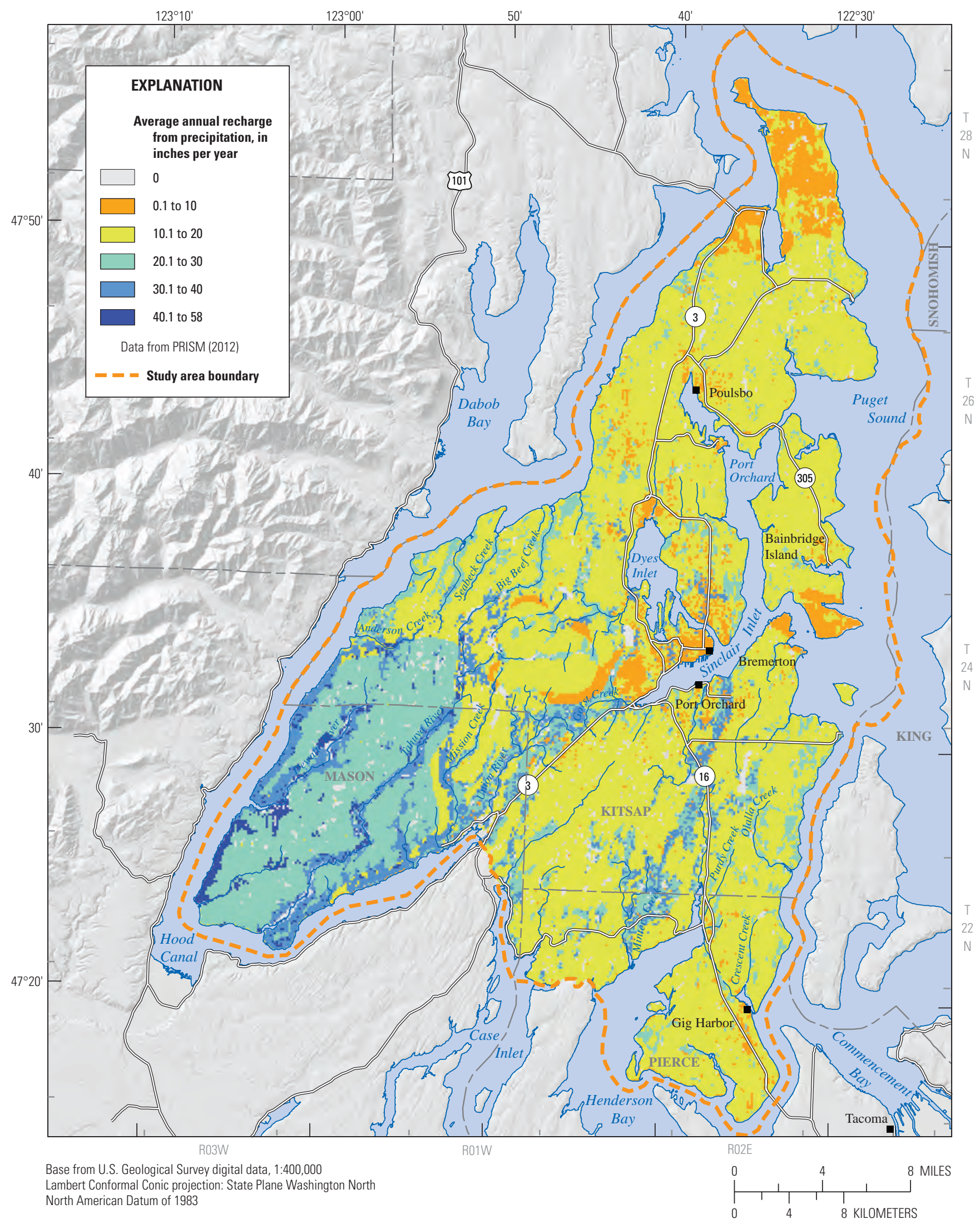

Figure 18. Distribution of average annual recharge from precipitation, Kitsap Peninsula, west-central Washington, 1980-2010. 
Recharge rates ranged from about $4 \mathrm{in} / \mathrm{yr}$ in the northern part of the study area, where precipitation amounts were about $25 \mathrm{in} / \mathrm{yr}$, to more than $55 \mathrm{in} / \mathrm{yr}$ in areas underlain by permeable aquifer deposits in river valleys in the southwestern part of the study area, where precipitation locally exceeds $80 \mathrm{in} / \mathrm{yr}$. When the recharge areas shown in figure 18 are summed, the groundwater-flow system in the study area receives about 523,680 acre-ft of recharge from precipitation during an average year. During 2012, when precipitation was above average, recharge from precipitation totaled 664,610 acre-ft. Most of the area typically receives between 10 and $18 \mathrm{in} / \mathrm{yr}$ of recharge.

Water use by humans also generates groundwater recharge from application of water to the land surface. On the Kitsap Peninsula, this includes septic system and irrigation return flows. The consumptive use rate for indoor domestic use was set at 10 percent in nonsewered areas, and the consumptive use rate for outdoor use was set at 90 percent (Washington State Department of Ecology, 2009). Consumptive use is the amount of water that is lost from the system through means such as evapotranspiration. Groundwater pumpage totals from public-supply systems were apportioned between sewered and nonsewered parts of the water-service area with only nonsewered areas having return flows. In addition to groundwater, the city of Bremerton also uses surface water from the Union River for some of its drinking water supply, so that amount of water used in nonsewered areas was included in the return-flow values. Total recharge in 2012 owing to return flows was 22,122 acre-ft.

\section{Groundwater Withdrawals}

Groundwater is the primary source for most water used on the Kitsap Peninsula. Groundwater is used for drinking water, irrigation, and fish hatcheries. The drinking water supply is divided between public-supply water systems and domestic self-supplied systems. Groundwater-pumping rates were estimated using two different methods to represent public-supply systems and domestic wells.

To estimate pumping rates for public-supply wells, locations of public-supply wells on the peninsula, along with the population served and number of connections, were obtained from Washington State Department of Health (2013). These public-supply systems mostly provided water for drinking and other domestic uses, but small quantities also were used for commercial and other purposes.

Large water purveyors were contacted to collect monthly pumpage data for 1985-2012, if available. For months with no recorded data, estimates were made by computing the average of months with recorded data for each given month. Public-supply systems with reported pumping rates served more than 221,700 people with more than 88,500 residential connections. Estimated indoor use (based on November-April pumping values) was 66 gallons per person per day (table 6). Outdoor use also was estimated for the outdoor growing season and varied by month from 4 gallons per person per day in May to 97 gallons per person per day in September.
Table 6. Monthly mean indoor and outdoor water-use rates for public-supply and self-supplied domestic water use, Kitsap Peninsula, west-central Washington, 1985-2012.

[Water-use rates are in gallons per person per day]

\begin{tabular}{lcc}
\hline \multirow{2}{*}{ Month } & \multicolumn{2}{c}{ Water use rate } \\
\cline { 2 - 3 } & Indoor & Outdoor \\
\hline January & 66 & 0 \\
February & 66 & 0 \\
March & 66 & 0 \\
April & 66 & 0 \\
May & 66 & 4 \\
June & 66 & 29 \\
July & 66 & 60 \\
August & 66 & 86 \\
September & 66 & 97 \\
October & 66 & 30 \\
November & 66 & 0 \\
December & 66 & 0 \\
\hline
\end{tabular}

Pumpage data from those systems that provided usage information were used to estimate pumpage for the remaining public-supply systems. About 47,000 people were served by public-supply systems for which pumping values were not reported. For the systems that did not provide their pumpage data, an estimate was made by taking the average total-perperson rate for a given month (table 6) and multiplying it by the population reported for that system. Locations and pumpage rates for all public-supply wells for 2012 are shown in figure 19. The total amount of groundwater withdrawals in 2012 for public supply purposes was 1,073 million cubic feet or 24,634 acre-ft.

Domestic self-supplied water is pumped for privately owned wells for domestic purposes such as drinking water and lawn watering. To estimate the amount of domestic self-supplied water use, the average monthly water use per person was applied to the population of users, which was estimated at about 43,400 . This population estimate is based on the total population of the Kitsap Peninsula from the 2010 census estimates (about 312,200 people) minus the population served by public-supply systems (about 268,800 people) (Washington State Office of Financial Management, 2012). The monthly mean use per person for domestic self-supplied water was assumed to be the same as the monthly mean water use per person for public-supplied water (table 6). The total amount of groundwater withdrawals in 2012 for domestic self-supply purposes was 4,455 acre-ft.

In addition to drinking water withdrawals, groundwater is also withdrawn for fish hatchery use and irrigation purposes. Hatcheries were contacted directly for their water-use information. Four hatcheries used 1,085 acre-ft of groundwater in their 2012 operations. Groundwater withdrawals for self-supplied irrigation of golf courses that was not previously accounted for in the public-supply category was 692 acre-ft based on usage information provided by the KPUD (Jason Nutsford, written commun., 2013). 


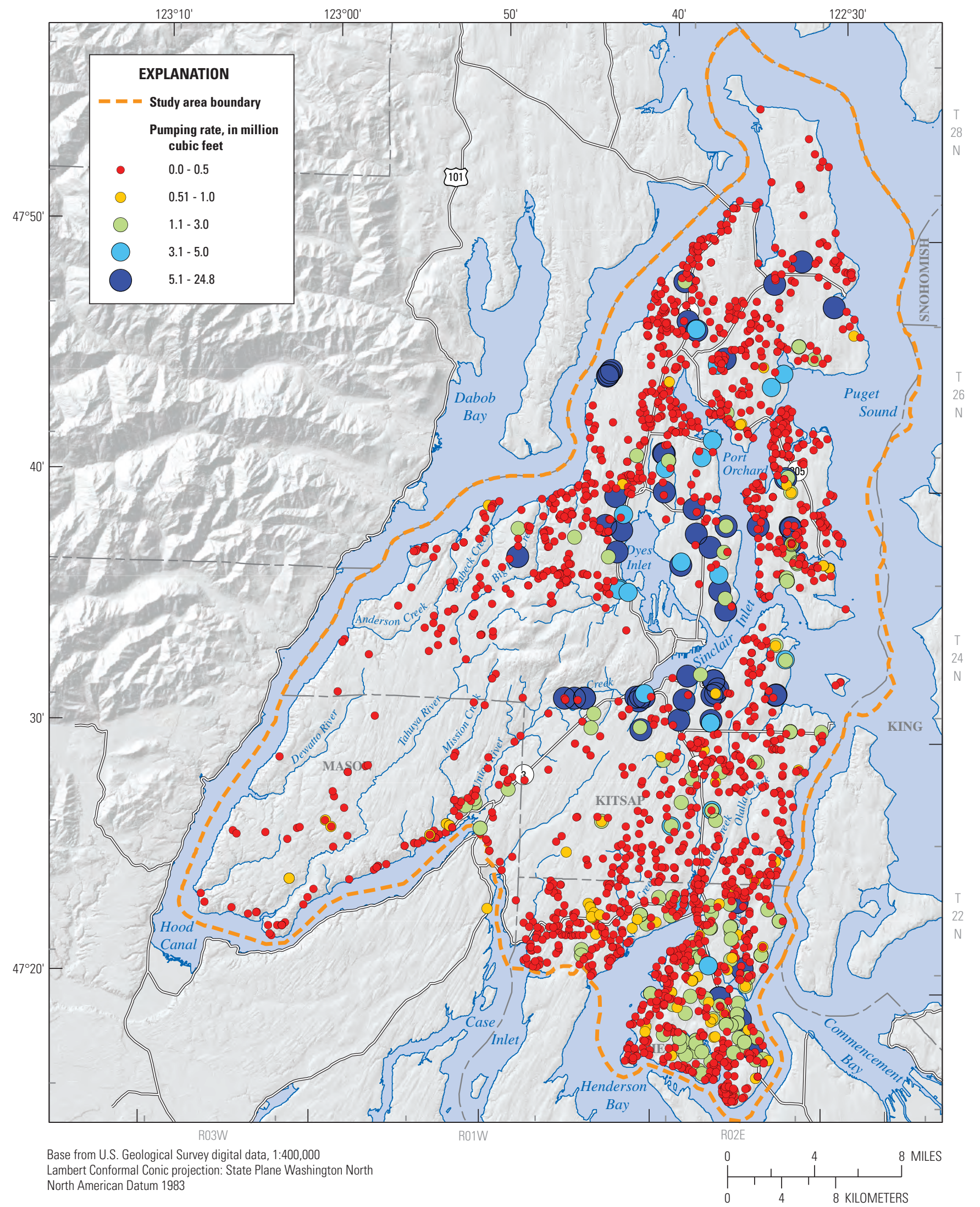

Figure 19. Locations of public-supply wells and pumping rates, Kitsap Peninsula, west-central Washington, 2012. 


\section{Discharge to Streams}

Groundwater discharge sustains the late-summer and early-autumn stream flow (base flow) of creeks and rivers in the study area. Estimates of groundwater discharge to streams in the study area were based on base flow discharge measured at 14 streamgages operated by the KPUD and the USGS that had a complete record for 2012 (fig. 4 and table 7). Hydrograph separation at 14 streamgages was conducted on the discharge records to estimate the groundwater contribution to streamflow using the Webbased Hydrograph Analysis Tool (WHAT) (Lim and others, 2005).

About $156 \mathrm{ft} 3 / \mathrm{s}$ (112,930 acre-ft/yr) of groundwater discharge to streams was measured during 2012. Groundwater discharge estimates represent flow from contributing areas upstream of the streamgages $\left(102.7 \mathrm{mi}^{2}\right)$. In the Kitsap Peninsula, $414.36 \mathrm{mi}^{2}$ of area drains to perennial streams (based on the National Hydrography Dataset medium-resolution streams). Using the total drainage area, the area-weighted base flow for the Kitsap Peninsula was estimated at $629 \mathrm{ft}^{3} / \mathrm{s}(455,550$ acre-ft/yr) for 2012, an above-average precipitation year. The use of an area-weighted estimate for groundwater discharge may not accurately represent the total annual groundwater discharge for the peninsula because of spatial variation in groundwater-discharge characteristics and likely introduces error into the calculations.

\section{Groundwater Flow}

The direction of groundwater movement is determined from water levels measured in wells that typically are screened in the aquifers. Groundwater moves from areas of high water-level altitudes to areas of low water-level altitudes. Groundwater levels measured during autumn and early winter of 2010-11 (igs. 20-23) were used to evaluate groundwater-flow directions in aquifers on the peninsula. Water-level contours were based on limited water-level data and are subject to uncertainty, so the groundwater-flow directions in figures 20-23 (for Qva, QA1, QA2, and QA3 aquifers) are generalized at the regional scale and do not necessarily reflect local-flow characteristics.

The Qva aquifer generally shows a radial flow pattern with flow moving from the central areas of the Kitsap Peninsula and Bainbridge Island toward the shorelines (fig. 20). Water-level altitudes range from more than $400 \mathrm{ft}$ above sea level in the southwest area of the Kitsap Peninsula and more than $300 \mathrm{ft}$ above sea level in the southwest area of Bainbridge Island to near $0 \mathrm{ft}$. along the shorelines. In areas where the water levels in Qva intersect the land surface, groundwater discharges to surface-water bodies. The vertical hydraulic gradient and flow direction in the Qva aquifer generally is downward in the interior areas of the peninsula and island and upward along the coastline, where the groundwater discharges to Puget Sound.
Table 7. Base flow discharge measured at streamgages used to determine groundwater discharge in the Kitsap Peninsula, westcentral Washington, 2012.

[Location of sites shown in figure 4. Description of Kitsap Public Utility District (KPUD) identifier shown in table $1 . \mathrm{ft}^{3} / \mathrm{s}$, cubic foot per second; $\mathrm{mi}^{2}$, square mile; - , no identifier]

\begin{tabular}{|c|c|c|c|}
\hline Station & $\begin{array}{c}\text { KPUD } \\
\text { identifier }\end{array}$ & $\begin{array}{c}\text { Base flow } \\
\left(\mathrm{ft}^{3} / \mathrm{s}\right)\end{array}$ & $\begin{array}{c}\text { Drainage } \\
\text { area } \\
\left(\mathrm{mi}^{2}\right)\end{array}$ \\
\hline Barker Creek & BA & 4.84 & 4.02 \\
\hline Big Beef Creek & $\mathrm{BB}$ & 33.3 & 13.8 \\
\hline Blackjack Creek & $\mathrm{BL}$ & 12.7 & 12.3 \\
\hline Burley Creek & $\mathrm{BC}$ & 22.2 & 10.7 \\
\hline Chico Creek tributary & CT & 13.5 & 9.28 \\
\hline Clear Creek - main stem & $\mathrm{CC}$ & 7.55 & 8.08 \\
\hline Curley Creek & $\mathrm{CU}$ & 20.4 & 14.2 \\
\hline $\begin{array}{l}\text { Dogfish Creek near } \\
\text { Poulsbo }\end{array}$ & DC & 7.59 & 5.09 \\
\hline Gold Creek & GO & 5.37 & 2.55 \\
\hline $\begin{array}{l}\text { Hansville Creek near } \\
\text { Port Gamble }\end{array}$ & $\mathrm{HC}$ & 0.41 & 1.01 \\
\hline Huge Creek & - & 9.90 & 6.47 \\
\hline Kitsap Creek & $\mathrm{KC}$ & 6.96 & 2.96 \\
\hline $\begin{array}{c}\text { Olalla Creek at Burley } \\
\text { Olalla Road, Olalla }\end{array}$ & $\mathrm{OL}$ & 9.08 & 7.51 \\
\hline $\begin{array}{l}\text { Steele Creek near mouth, } \\
\text { near Brownsville }\end{array}$ & $\mathrm{SL}$ & 2.20 & 4.75 \\
\hline Total & & 156.00 & 102.7 \\
\hline
\end{tabular}

The QA1 aquifer also shows a radial flow pattern with flow moving from the central areas of the Kitsap Peninsula and Bainbridge Island toward the shorelines (fig. 21). Water-level altitudes range from more than $300 \mathrm{ft}$ above sea level in the southwest interior of the peninsula and more than $150 \mathrm{ft}$ above sea level in the center of the island to near zero along the shorelines. As with the Qva aquifer, the vertical hydraulic gradient and flow direction in this aquifer generally is downward in the interior areas and upward along the coastline, where the groundwater discharges to Puget Sound.

Determining water-level flow directions in QA2 and QA3 is somewhat difficult because of the limited number of wells with water-level data in those units. For QA2, an area of high water levels is in the north-central area of the Kitsap Peninsula that flows radially outward (fig. 22). An area of high water levels also is in the south-central area of the peninsula that appears to flow radially outward.

In the QA3 aquifer, water-level contours are shown only for the northern area of the study area. An area of high water levels is in the north-central area of the Kitsap Peninsula that flows radially offshore (fig. 23). The lowest measured water level was on Bainbridge Island where flow appears to converge from all sides. In the southern area of the peninsula, insufficient water levels were present to draw contour lines. 


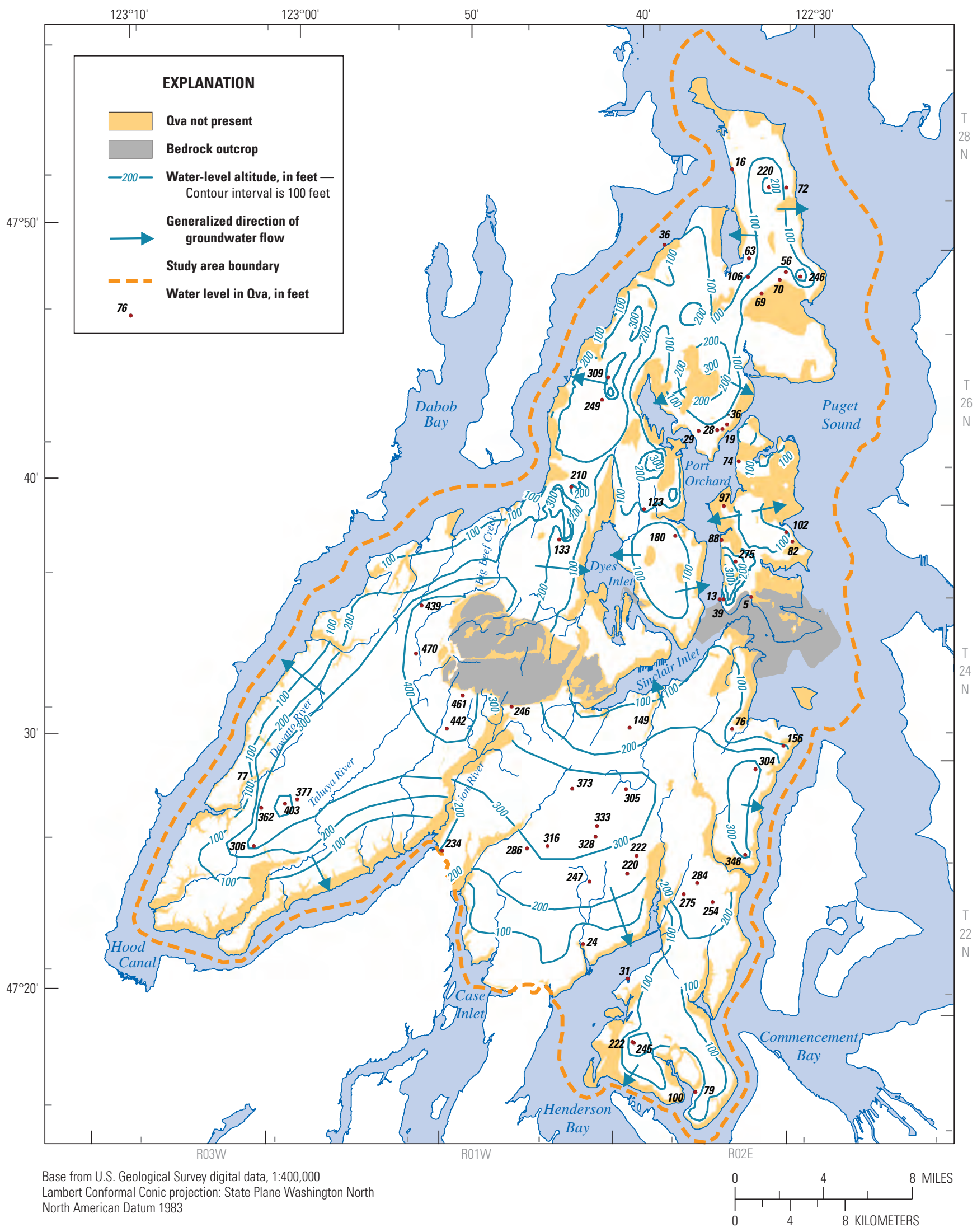

Figure 20. Water-level altitudes and generalized direction of groundwater flow in the Vashon advance aquifer (Qva), Kitsap Peninsula, west-central Washington, autumn 2010. 


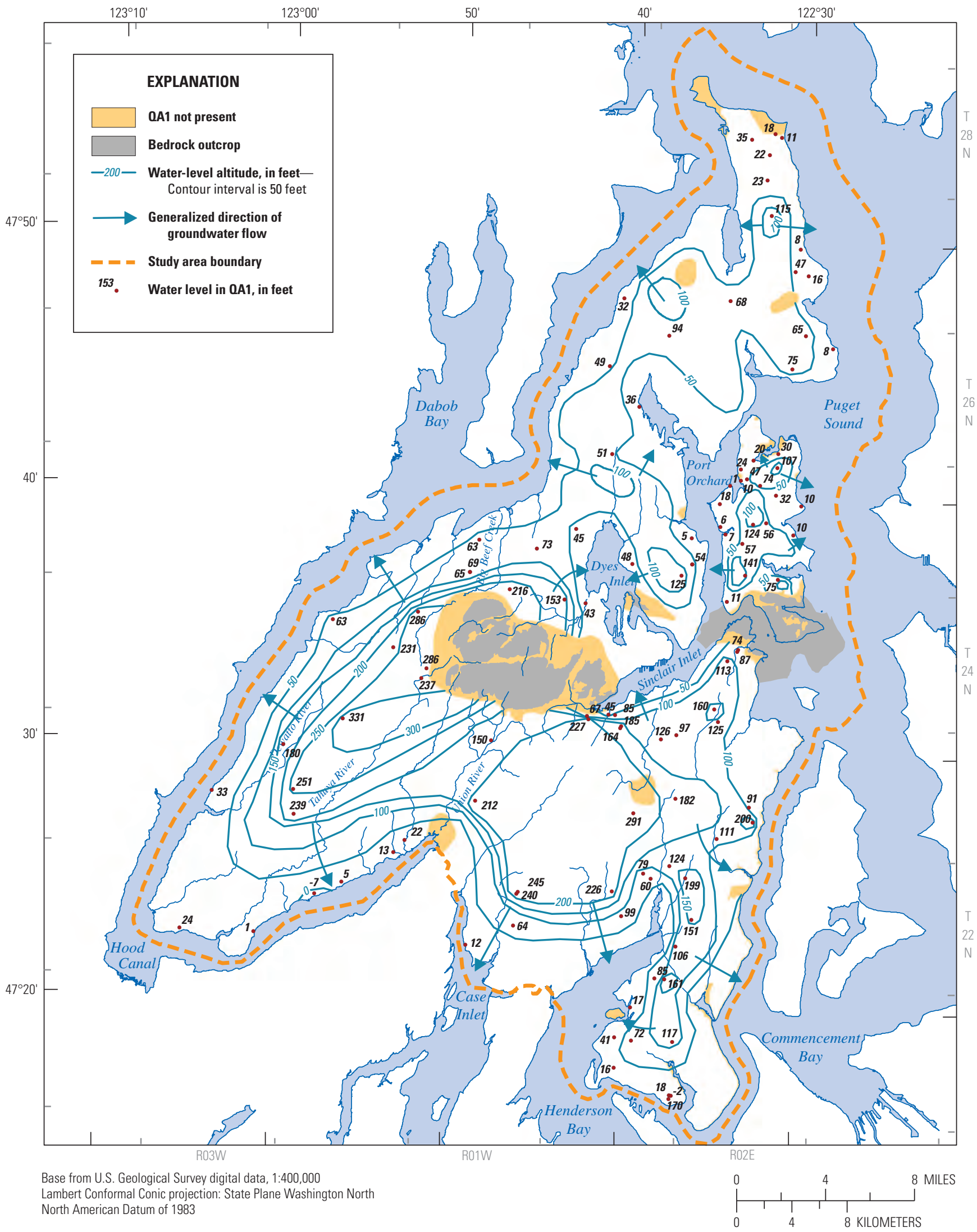

Figure 21. Water-level altitudes and generalized direction of groundwater flow in the sea level aquifer (QA1), Kitsap Peninsula, west-central Washington, autumn 2010. 


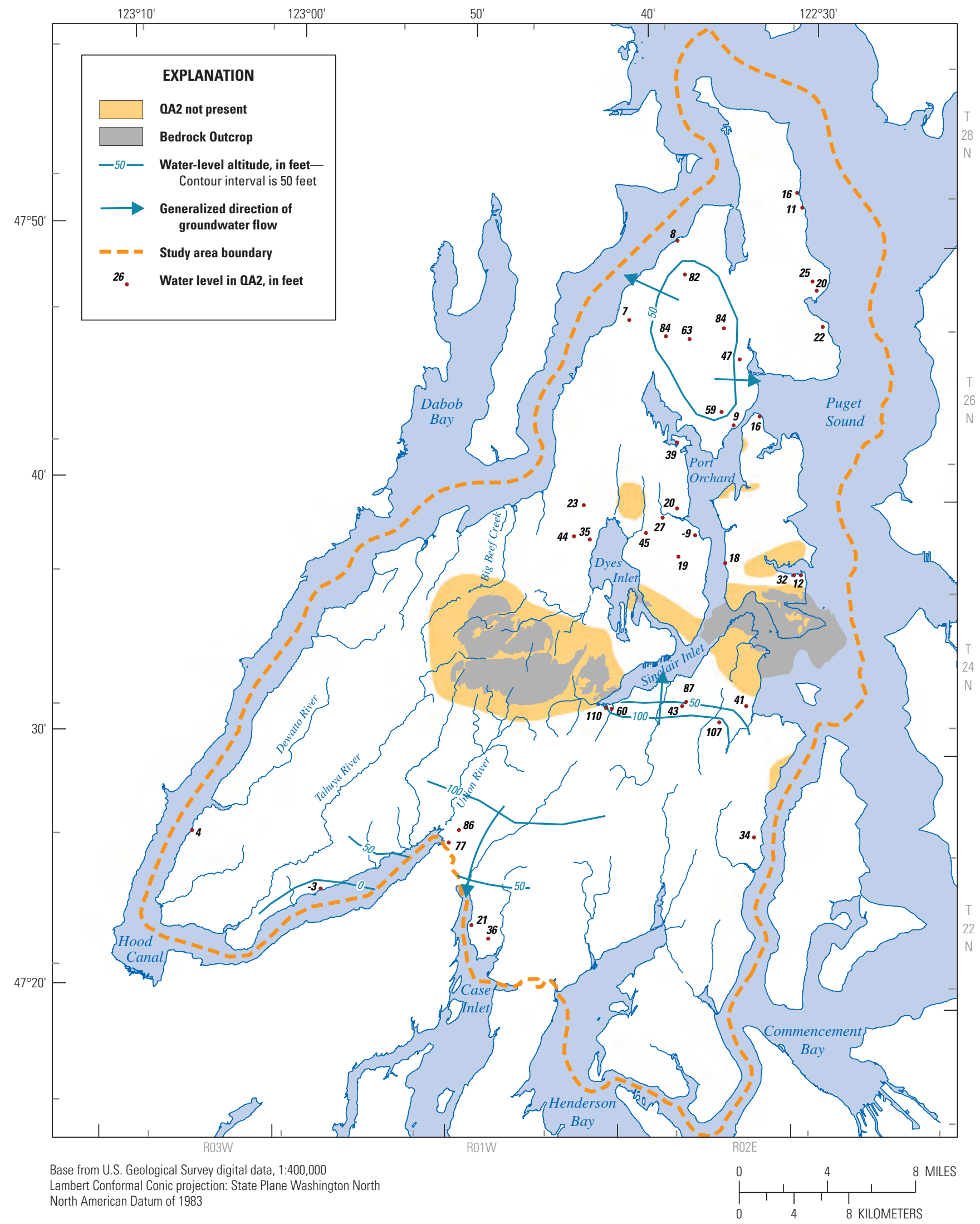

Figure 22. Water-level altitudes and generalized direction of flow in the glaciomarine aquifer (0A2), Kitsap Peninsula, west-central Washington, autumn 2010. 


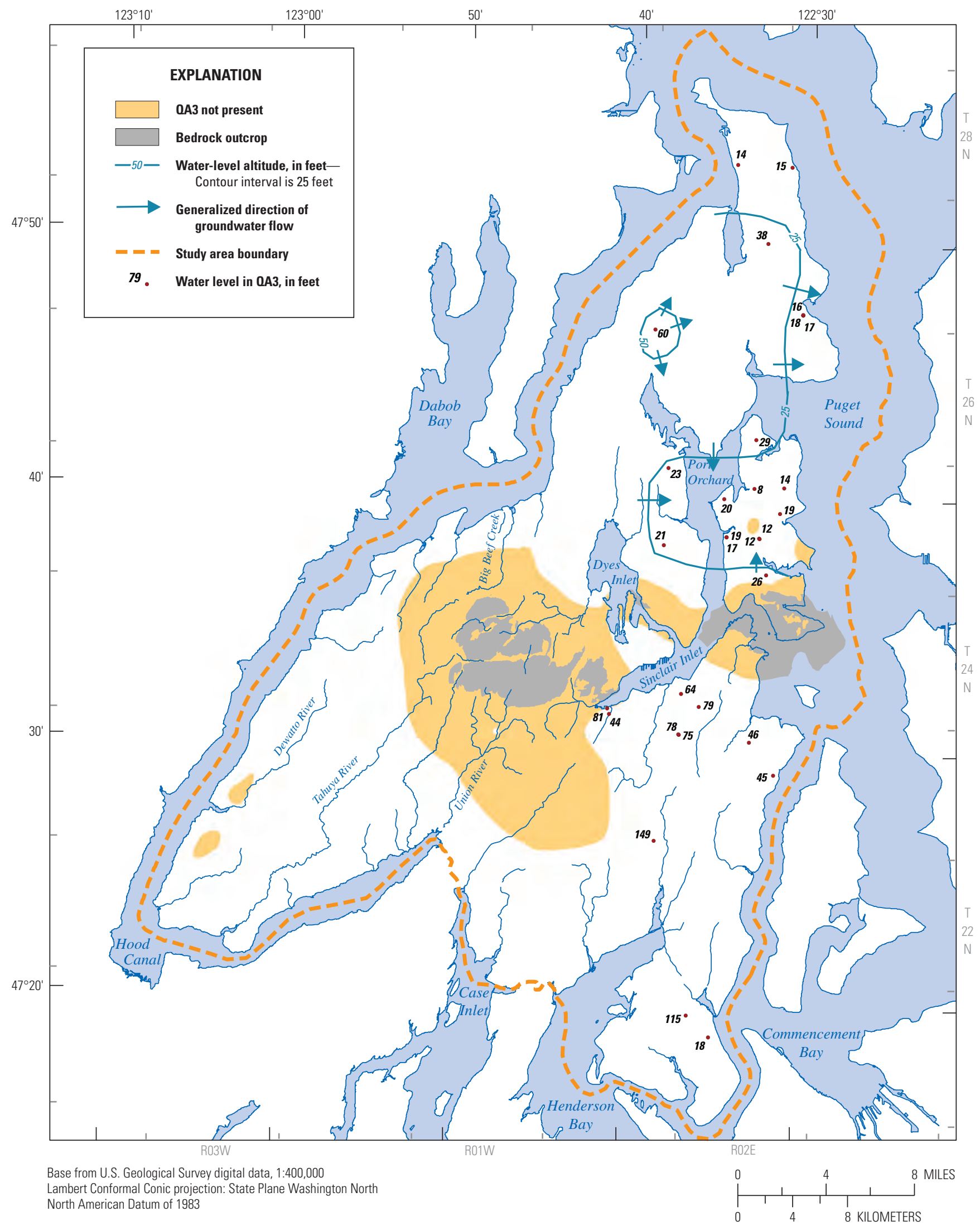

Figure 23. Water-level altitudes and generalized direction of flow in the deep aquifer (QA3), Kitsap Peninsula, west-central Washington, autumn 2010. 


\section{Groundwater-Level Fluctuations}

Groundwater levels fluctuate over time, both seasonally and in the long term, in response to changing rates of groundwater recharge and discharge. When recharge exceeds discharge, the amount of water stored in an aquifer increases and water levels rise; when discharge exceeds recharge, groundwater storage decreases and water levels decline. Groundwater levels also may respond to changes in nearby stream stage. When stream stage (altitude of the water surface) exceeds nearby groundwater levels, streamflow may recharge the aquifer, causing a rise in groundwater levels; when groundwater levels exceed nearby stream stage, discharge from the aquifer to the stream may occur, resulting in a decline in groundwater levels. Seasonal changes in water levels were observed in many wells in the study area. These water-level changes follow a typical pattern for shallow wells in western Washington. Water levels rose in autumn and winter when precipitation and river stage were high, and declined during spring and summer when precipitation and river stage were low (figs. 24 and 25). Peak water levels lagged behind the peak streamflow by a few months, reflecting the storage characteristics of the groundwater system-also a typical pattern for western Washington. Wells that are finished in shallower aquifers such as 22N/01E-29H04, which is in the Qva aquifer, more closely track to the pattern of the streamflow hydrograph than do wells finished in deeper aquifers such as $26 \mathrm{~N} / 01 \mathrm{E}-02 \mathrm{~K} 02$, which is in the QA1 aquifer (figs. 24 and 25).

The timing and magnitude of seasonal water-level fluctuations in an aquifer system are related to (1) the hydraulic characteristics of aquifer materials and adjacent confining units, (2) the presence of unconfined or confined aquifer conditions, (3) the depth to groundwater, (4) the proximity to perennial surface-water features, and (5) the depth of the well and screened intervals being measured. Water levels in deep wells typically respond more slowly and with less magnitude than water levels in shallow wells because deep wells are farther from the recharge source and variability is dampened. Water levels in wells completed in the unconsolidated hydrogeologic units showed seasonal variations ranging from 1 to about $20 \mathrm{ft}$ (table 8). The largest water-level fluctuation $(33.31 \mathrm{ft}$ ) during the monitoring period was measured in a well completed in the bedrock unit. Large water-level fluctuations in wells completed in the bedrock unit may be attributed to the presence of water-bearing fractures (high conductivity and low storage) within local outcrop areas receiving precipitation recharge, and the relatively lower (compared to sands and gravels) storage capacity (primary porosity) of consolidated volcanic and sedimentary units (Freeze and Cherry, 1979; Fetter, 1994).

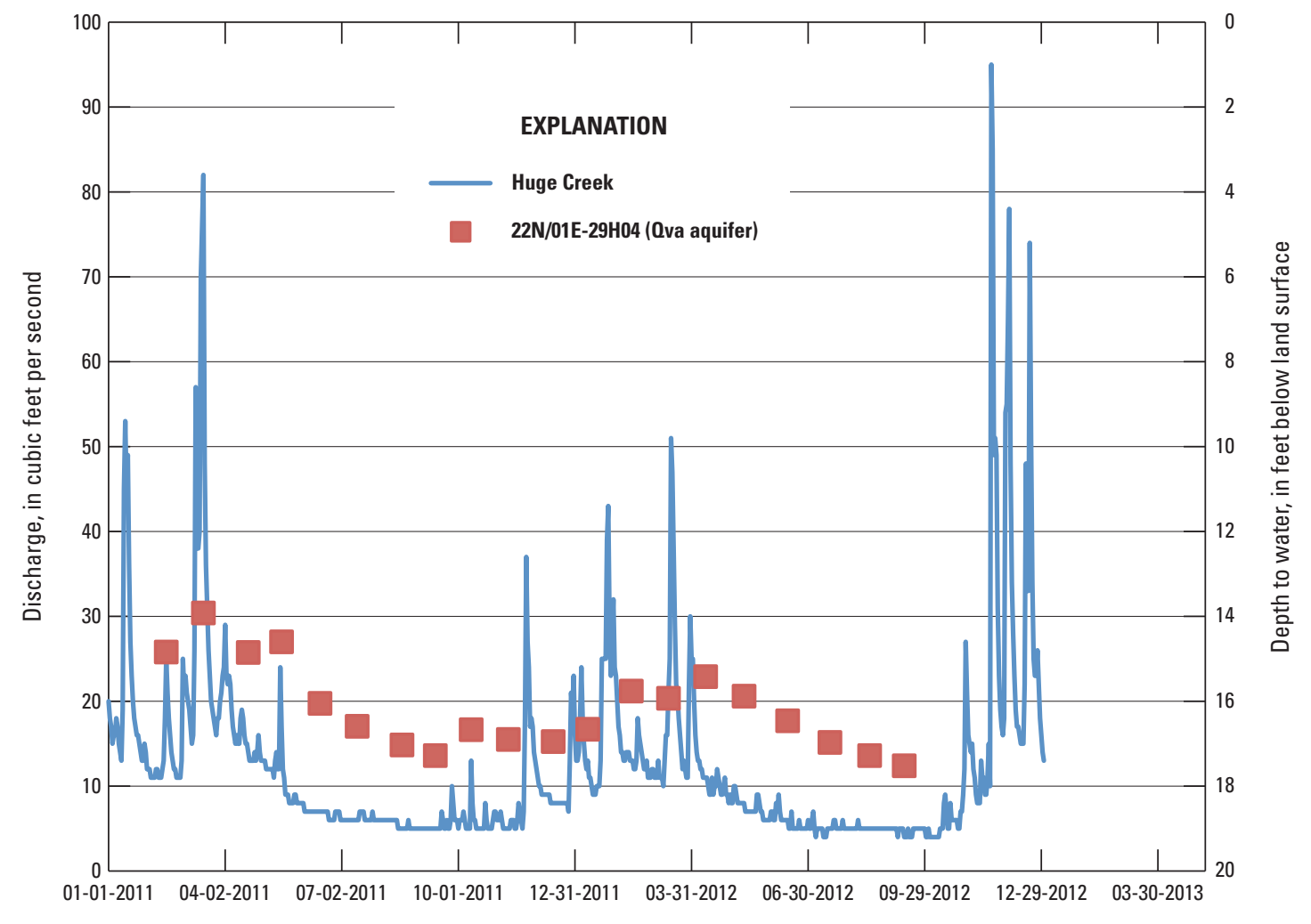

Figure 24. Water levels in well 22N/01E-29H04 and discharge at the Huge Creek streamgaging station (12073500), Kitsap Peninsula, west-central Washington, October 2011-January 2013. 


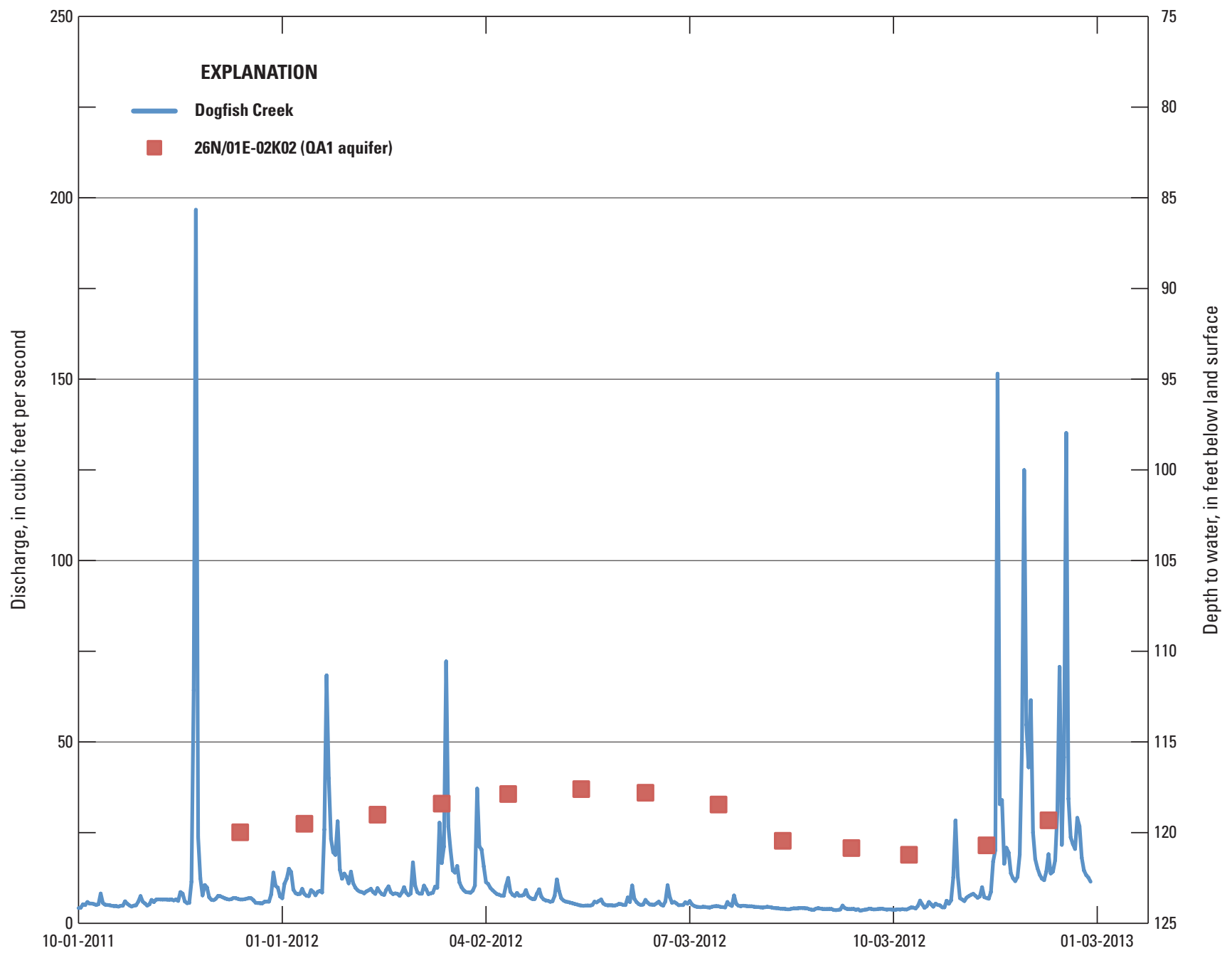

Figure 25. Water levels in well 26N/01E-02K02 and discharge at the Dogfish Creek streamgaging station (12070000), Kitsap Peninsula, west-central Washington, October 2011-January 2013. Location of well is shown on plate 1.

Table 8. Statistical summary of water-level fluctuations and well depth by hydrogeologic unit, Kitsap Peninsula, westcentral Washington, 2011-12.

\begin{tabular}{|c|c|c|c|c|c|c|c|}
\hline \multirow{2}{*}{ Hydrogeologic unit } & \multirow{2}{*}{$\begin{array}{l}\text { Number of } \\
\text { wells }\end{array}$} & \multicolumn{3}{|c|}{ Water-level fluctuations (feet) } & \multicolumn{3}{|c|}{ Well depth (feet) } \\
\hline & & Minimum & Median & Maximum & Minimum & Median & Maximum \\
\hline Qvr, Vashon recessional aquifer & 3 & 1.11 & 10.8 & 12.7 & 42.0 & 45.0 & 56.0 \\
\hline Qvt, Vashon till confiing unit & 1 & 3.69 & 3.69 & 3.69 & 42.0 & 42.0 & 42.0 \\
\hline Qva, Vashon advance aquifer & 19 & 1.10 & 4.44 & 20.5 & 30.0 & 101 & 391 \\
\hline QC1pi, permeable interbeds & 2 & 1.78 & 3.18 & 4.58 & 91.0 & 129 & 168 \\
\hline QA1, sea-level aquifer & 32 & 1.00 & 2.93 & 13.8 & 49.0 & 269 & 465 \\
\hline QA2, glaciomarine aquifer & 6 & 2.06 & 2.34 & 2.79 & 235 & 366 & 478 \\
\hline QA3, deep confining unit & 1 & 1.46 & 1.46 & 1.46 & 873 & 873 & 873 \\
\hline BR, bedrock & 1 & 33.3 & 33.3 & 33.3 & 264 & 264 & 264 \\
\hline
\end{tabular}




\section{Groundwater Budget}

On a long-term basis, a hydrologic system usually is in a state of dynamic equilibrium; that is, inflow to the system equals outflow from the system, and there is little or no net change in the amount of water stored in the system. A simplified, approximate water budget for 2012 for the study area was calculated (table 9 ). The water budget assumes that there is little or no net change in the amount of water stored in the system (inflow equals outflow) and can be represented by the following equation:

$$
R_{p p t}+R_{R F}=D_{p p g}+D_{s w}+D_{s s}
$$

where

$R_{p p t}$ is recharge from precipitation, in acre-feet,

$R_{R F}$ is recharge from septic system and irrigation return flows, in acre-feet,

$D_{p p g}$ is discharge from wells, in acre-feet,

$D_{s w}$ is discharge to streams, in acre-feet, and

$D_{s s}$ is discharge to other natural features, in acre-feet.
The data and methods used to estimate values for the water budget are described in the sections, "Recharge," "Groundwater Withdrawals," and "Discharge to Streams." Uncertainties in these components arise from the use of area-weighted approximations of recharge and groundwater discharge to streams and groundwater withdrawal estimates for smaller public supply and domestic systems based on data for larger public-supply systems. The water budget is intended to provide an initial gross estimate of groundwater budget components, and because of these limitations, should be considered an approximation of a complex system.

For 2012, virtually all of the groundwater recharge (97 percent) comes from precipitation and only 3 percent comes from return flows (table 9). Most of this recharge (66 percent) discharged to streams, and only about 4 percent was withdrawn from wells. The remaining groundwater recharge (30 percent) left the groundwater system as discharge to Hood Canal and Puget Sound.

Table 9. Estimated annual water budget for the groundwater system of the Kitsap Peninsula, west-central Washington, 2012.

[Values may not sum to 100 due to rounding]

\begin{tabular}{lrrr}
\hline \multicolumn{1}{c}{ Water-budget component } & Acre-feet & & Percent \\
\hline Groundwater recharge & & & \\
From precipitation & 664,610 & & 97 \\
From return flows & 22,122 & 3 \\
$\quad$ & 686,732 & & 100 \\
$\quad$ Total & & \\
Fate of recharge & 455,550 & \\
$\quad$ Discharge to streams & 200,316 & 66 \\
Other natural discharge & 30,866 & 30 \\
Withdrawals from wells & 686,732 & \\
$\quad$ Total & & 100 \\
\hline
\end{tabular}




\section{Summary}

Groundwater is the primary source of drinking water for most of the population of the Kitsap Peninsula. Therefore, as the population grows, so does the demand for groundwater. The quantity of usable groundwater likely is limited, however, mostly because of the peninsula geography and the potential for water-level declines, decreases in the groundwater discharge to streams, and seawater intrusion as groundwater usage increases.

The Kitsap Peninsula lies in the Puget Sound lowland of west-central Washington, is bounded by Puget Sound on the east and Hood Canal on the west, and covers an area of about 575 square miles. The Peninsula encompasses all of Kitsap County, part of Mason County north of Hood Canal, and part of Pierce County west of Puget Sound. The peninsula is surrounded by saltwater and has a hydrologic setting similar to that of an island. The study area is incised by many small rivers and streams that flow from the interior of the peninsula to Puget Sound and Hood Canal. Many rivers and streams flow year-round and are fed by springs and surface runoff after storms. Where cliffs are present along the coastline, springs and seeps discharge water directly onto the beach and into Puget Sound. Glacial and interglacial deposits that constitute much of the subsurface of the study area are exposed in cliffs along many shorelines. The deposits consist primarily of alternating layers of glacial till, sand and gravel, and silt and clay. Bedrock, which generally underlies the glacial and interglacial deposits, ranges in depth from exposure at the land surface to an estimated 2,000 feet below land surface.

Geologic units were grouped into 12 hydrogeologic units consisting of aquifers, confining units, and bedrock. A surficial hydrogeologic unit map was developed and used with well information from 2,116 drillers' logs to produce 6 hydrogeologic sections and unit extent and thickness maps.

Unconsolidated aquifers (Vashon recessional aquifer [Qvr], Vashon advance aquifer [Qva], permeable interbeds [QC1pi], sea-level aquifer [QA1], glaciomarine aquifer [QA2], and deep aquifer [QA3]) typically consist of moderately to well-sorted alluvial and glacial outwash deposits of sand, gravel, and cobbles, with minor lenses of silt and clay. These units often occur as discontinuous or isolated bodies and are of highly variable thickness. Unconfined conditions occur in areas where aquifer units are at land surface; however, much of the study area is mantled by glacial till, and confined aquifer conditions are common. Groundwater in the unconsolidated aquifers generally flows radially off of the peninsula in the direction of Puget Sound and Hood Canal. These generalized flow patterns likely are complicated by the presence of low-permeability confining units that separate discontinuous bodies of aquifer material and act as local groundwater-flow barriers.

Unconsolidated confining units (Vashon till [Qvt], upper [QC1], middle [QC2], lower [QC3] and basal [QC4]) typically consist of poorly sorted glacial till, and glaciolacustrine and interglacial deposits of clay, silt, sand, gravel, cobbles, and boulders, with a few locally occurring sand and gravel lenses capable of providing water for domestic use. Unconsolidated aquifer and confining units are underlain by Tertiary bedrock units primarily consisting of sedimentary claystone, siltstone, sandstone, and volcanic rocks. These units, described as the basement confining unit, are not considered part of the active groundwater-flow system.

Groundwater-level fluctuations during the monitoring period (2011-12) in wells completed in unconsolidated hydrogeologic units indicated seasonal variations ranging from 1 to about 20 feet. The largest fluctuation of 33 feet was in a well that was completed in the bedrock unit. Stream-discharge measurements made during 2012 indicate that groundwater discharge to streams (base flow) in the area ranged from about 0.41 to 33.3 cubic feet per second.

During 2012, which was an above-average year of precipitation, the groundwater system received about 664,610 acre-feet of recharge from precipitation and 22,122 acre-feet of recharge from septic and irrigation return flows. Most of this annual recharge (66 percent) discharged to streams, and only about 4 percent was withdrawn from wells. The remaining groundwater recharge (30 percent) left the groundwater system as discharge to Hood Canal and Puget Sound. 


\section{References Cited}

Bear, Jacob, 1979, Hydraulics of groundwater: New York, McGraw-Hill, 569 p.

Bidlake, W.R., and Payne, K.L., 2001, Estimating recharge to ground water from precipitation at Naval Submarine Base Bangor and vicinity, Kitsap County, Washington: U.S. Geological Survey Water-Resources Investigations Report 2001-4110, 33 p.

Booth, D.B., and Troost, K.G., 2005, Geologic map of the Olalla 7.5-minute quadrangle, King, Kitsap, and Pierce Counties, Washington: U.S. Geological Survey Scientific Investigations Map 2902, scale 1:24,000.

Contreras, T.A., Paulin, G.L., Czajkowski, J.L., Polenz, M., Logan, R.L., Carson, R.J., Mahan, S.A., Walsh, T.J., Johnson, C.N., and Skov, R.H.,, 2010, Geologic map of the Lilliwaup 7.5-minute quadrangle, Mason County, Washington: Washington State Department of Natural Resources, Division of Geology and Earth Resources Open File Report 2010-4, scale 1:24,000.

Contreras, T.A., Weeks, S.A., Stanton, K.M.D., Stanton, B.W., Perry, B.B., Walsh, T.J., Carson, R.J., Clark, K.P., and Mahan, S.A., 2011, Geologic map of the Holly 7.5-minute quadrangle, Jefferson, Kitsap and Mason Counties, Washington: Washington State Department of Natural Resources, Division of Geology and Earth Resources Open File Report 2011-5, scale 1:24,000.

Cunningham, W.L., and Schalk, C.W., comps., 2011, Groundwater technical procedures of the U.S. Geological Survey: U.S. Geological Survey Techniques and Methods, book 1, chap. A1, 151 p. [Also available at http://pubs.usgs.gov/tm/1a1/.]

Deeter, J.D., 1979, Quaternary geology and stratigraphy of Kitsap County, Washington: Bellingham, Western Washington University, M.S. thesis, 175 p.

Derkey, R.E., Hehemann, N.J., and Alldritt, K., 2009, Geologic map of the Lake Wooten 7.5-minute quadrangle, Mason County, Washington: Washington State Department of Natural Resources; Division of Geology and Earth Resources Open File Report 2009-5, scale 1:24,000.

Dion, N.P., Olsen, T.D., and Payne, K.L., 1988, Preliminary evaluation of the ground-water resources of Bainbridge Island, Kitsap County, Washington: U.S. Geological Survey Water-Resources Investigations Report 87-4237, 82 p.

Drost, B.W., 1982, Water resources of the Gig Harbor Peninsula and adjacent areas, Washington: U.S. Geological Survey Water-Resources Investigations Open-File Report 81-1021, 148 p.
Ferris, J.G., Knowles, D.B., Brown, R.H., and Stallman, R.W., 1962, Theory of aquifer tests: U.S. Geological Survey Water-Supply Paper 1536-E, 174 p.

Fetter, C.W., 1994, Applied hydrogeology (3d ed.): Englewood Cliffs, N.J., Prentice Hall, 691 p.

Frans, L.M., Bachmann, M.P., Sumioka, S.S., and Olsen, T.D., 2011, Conceptual model and numerical simulation of the groundwater-flow system of Bainbridge Island, Washington: U.S. Geological Survey Scientific Investigations Report 2011-5021, 96 p.

Freeze, R.A., and Cherry, J.A., 1979, Groundwater: Englewood Cliffs, N.J., Prentice-Hall, 604 p.

Fry, J.A., Xian, George, Jin, Suming, Dewitz, J.A., Homer, C.G., Yang, Limin, Barnes, C.A., Herold, N.D., and Wickham, J.D, 2011, Completion of the 2011 National Land Cover Database for the conterminous United States: Programmatic Engineering \& Remote Sensing, v. 77, no. 9, p. 858-864. [Also available at www.mrlc.gov/ downloadfile2.php?file=September2011PERS.pdf.]

Fulmer, C.V., 1975, Stratigraphy and paleontology of the type Blakeley and Blakely Harbor formations, in Weaver, D.W., Hornaday, G.R., and Tipton, A., eds., Paleogene symposium and selected technical papers; conference on future energy horizons of the Pacific Coast: American Association of Petroleum Geologists, Pacific Section, p. 210-271.

Garling, M.E., Molenaar, Dee, and others, 1965, Water resources and geology of the Kitsap Peninsula and certain adjacent islands: Olympia, Wash., Washington Department of Conservation, Washington Division of Water Resources Water Supply Bulletin 18, 309 p. [Also available at http:// www.ecy.wa.gov/programs/eap/wsb/pdfs/WSB_18_Book. pdf.]

Hansen, A.J., and Bolke, E.L., 1980, Ground-water availability on the Kitsap Peninsula, Washington: U.S. Geological Survey Water-Resources Investigations Open-File Report 80-1186, 65 p.

Hutchinson, M.F., 1989, A new method for gridding elevation and streamline data with automatic removal of pits: Journal of Hydrology, v.106, p.211-232.

Jones, M.A., 1996, Thickness of unconsolidated deposits of the Puget Sound aquifer system, Washington and British Columbia: U.S. Geological Survey Water-Resources Investigations Report 94-4133, 1 pl., scale 1:500,000.

Jones, M.A., 1999, Geologic framework of the Puget Sound aquifer system, Washington and British Columbia: U.S. Geological Survey Professional Paper 1424-C, 31 p. 
Kahle, S.C., 1998, Hydrogeology of Naval Submarine Base Bangor and vicinity, Kitsap County, Washington: U.S. Geological Survey Water-Resources Investigations Report 97-4060, 107 p.

Kato and Warren, Inc., and Robinson and Noble, Inc., 2000, City of Bainbridge Island level II assessment-An element of the water resources study: State of Washington [variously paged], accessed January 10, 2011, at http://www.kpud. org/water/reference/docs/bainbridgeisland/Bainbridge $\% 20$ Island\%20Level\%20II\%20Assessment.pdf.

Kitsap County Ground Water Advisory Committee, Economic and Engineering Services, Inc., Hart-Crowser, Inc., Pacific Groundwater Group, and Robinson and Noble, Inc., 1989, Kitsap County ground water management plan - Grant no. 1-Background data collection and management issues: Olympia, Wash., Economic and Engineering Services, Inc., $2 \mathrm{v}$.

Lane, R.C., 2009, Estimated water use in Washington, 2005: U.S. Geological Survey Scientific Investigations Report 2009-5128, 30 p.

Lim, K.J., Engel, B.A., Tang, Zhenxu, Choi, Joongdae, Kim, Ki-Sung, Muthukrishnan, Suresh, and Tripathy, Dibyajyoti, 2005, Automated Web GIS based Hydrograph Analysis Tool, WHAT: Journal of the American Water Resources Association, v. 41, no. 6, p. 1407-1416.

Logan, R.L., Walsh, T.J., and Troost, K.G., 2006, Geologic map of the Fox Island 7.5-minute quadrangle, Pierce County, Washington: Washington State Department of Natural Resources; Division of Geology and Earth Resources, Geologic Map GM-63, scale 1:24,000.

Lum, W.E., II, 1979, Water resources of the Port Madison Indian Reservation, Washington: U.S. Geological Survey Water-Resources Investigations 78-112, 73 p.

Polenz, M., Alldritt, K., Hehemann, N.J., and Logan, R.L., 2009a, Geologic Map of the Burley 7.5-minute quadrangle, Kitsap, and Pierce Counties, Washington: Washington State Department of Natural Resources; Division of Geology and Earth Resources Open File Report 2009-8, scale 1:24,000.

Polenz, M., Alldritt, K., Hehemann, N.J., Sarikhan, I.Y., and Logan, R.L., 2009b, Geologic map of the Belfair 7.5-minute quadrangle, Mason, Kitsap, and Pierce Counties, Washington: Washington State Department of Natural Resources; Division of Geology and Earth Resources Open File Report 2009-7, scale 1:24,000.

PRISM Climate Group, 2012, PRISM climate data: Corvallis, Oregon State University PRISM Climate Group database, accessed February 2012, at http://prism.oregonstate.edu/.
Puget Sound LiDAR Consortium, 2000, PSLC 2000-Bare Earth LiDAR DEM: Puget Sound LiDAR Consortium Web site, accessed September 20, 2007, at http://pugetsoundlidar. ess.washington.edu.

Rantz, S.E., and others, 1982, Measurement and computation of streamflow-Volume 1-Measurement of stage and discharge: U.S. Geological Survey Water-Supply Paper 2175, 284 p. [Also available at http://pubs.usgs.gov/wsp/ wsp2175.]

Savoca, M.E., Johnson, K.H., Sumioka, S.S., Olsen, T.D., Fasser, E.T., and Huffman, R.L., 2009, Hydrogeologic framework, groundwater movement, and water budget in tributary subbasins and vicinity, lower Skagit River Basin, Skagit and Snohomish Counties, Washington: U.S. Geological Survey Scientific Investigations Report 2009-5270, 46 p.

Sceva, J.E., 1957, Geology and ground-water resources of Kitsap County, Washington: U.S. Geological Survey Water Supply Paper 1413, 178 p.

Tabor, R.W., Haugerud, R.A., Haeussler, P.J., and Clark, K.P., 2011, Lidar-revised geologic map of the Wildcat Lake 7.5' quadrangle, Kitsap and Mason Counties, Washington: U.S. Geological Survey Scientific Investigations Map 3187, scale 1:24,000.

U.S. Department of Agriculture, 2004, Soil Survey Geographic (SSURGO) database for Kitsap County, Washington: U.S. Department of Agriculture, Natural Resources Conservation Service Web site, accessed August 2009, at http://soils.usda. gov/survey/geography/ssurgo.

Vaccaro, J.J., Hansen, A.J., Jr., and Jones, M.A., 1998, Hydrogeologic framework of the Puget Sound aquifer system, Washington and British Columbia: U.S. Geological Survey Professional Paper 1424-D, 77 p.

Washington State Department of Ecology, 2009, Final cost benefit, maximum net benefit, and least burdensome analyses-Chapter 173-517, Washington administrative code water resources program for the Quilcene-Snow watershed, Water Resources Inventory Area (WRIA) 17: Washington State Department of Ecology Publication no. 09-11-029.

Washington State Department of Health, 2013, Water system data for download: Washington State Department of Health database, accessed July 2013 at http://www.doh. wa.gov/DataandStatisticalReports/EnvironmentalHealth/ DrinkingWaterSystemData/DataDownload.aspx. 
Washington State Office of Financial Management, 2012, Get GIS data - Census 2010 Tiger/Line shapefiles: Washington State Office of Financial Management database, accessed July 2013 at http://www.ofm.wa.gov/pop/geographic/ default.asp.

Weaver, C.E., 1916, The tertiary formations of western Washington: Washington State Geological Survey, v. 13, 319 p.
Western Region Climate Center, 2013, Monthly climate summary-Bremerton, Washington: Western Region Climate Center database, accessed September 2013 at http:// www.wrcc.dri.edu/cgi-bin/cliMAIN.pl?wa0872.

Yount, J.C. and Gower, H.D., 1991, Bedrock geologic map of the Seattle $30^{\prime}$ by $60^{\prime}$ quadrangle, Washington: U.S. Geological Survey Open File Report 91-147, 37 p., 4 pls., scale 1:100,000. 
Publishing support provided by the U.S. Geological Survey

Publishing Network, Tacoma Publishing Service Center

For more information concerning the research in this report, contact the Director, Washington Water Science Center

U.S. Geological Survey

934 Broadway, Suite 300

Tacoma, Washington 98402

http://wa.water.usgs.gov 
